\title{
Sea-level change during the last 2500 years in New Jersey, USA
}

\author{
Andrew C. Kemp ${ }^{\mathrm{a}, *}$, Benjamin P. Horton ${ }^{\mathrm{b}, \mathrm{c}}$, Christopher H. Vane ${ }^{\mathrm{d}}$, \\ Christopher E. Bernhardt ${ }^{\mathrm{e}}$, D. Reide Corbett $^{\mathrm{f}}$, Simon E. Engelhart ${ }^{\mathrm{g}}$, Shimon C. Anisfeld ${ }^{\mathrm{h}}$, \\ Andrew C. Parnell ${ }^{\mathrm{i}}$, Niamh Cahill ${ }^{\mathrm{i}}$
}

${ }^{a}$ Department of Earth and Ocean Sciences, Tufts University, Medford, MA 02155, USA

${ }^{\mathrm{b}}$ Institute of Marine and Coastal Sciences, Rutgers University, New Brunswick, NJ 08901, USA

${ }^{c}$ Division of Earth Sciences and Earth Observatory of Singapore, Nanyang Technological University, 639798 Singapore, Singapore

${ }^{\mathrm{d}}$ British Geological Survey, Keyworth, Nottingham NG12 5GG, UK

e United States Geological Survey, National Center, Reston, VA 20192, USA

${ }^{\mathrm{f}}$ Department of Geological Science, East Carolina University, Greenville, NC 27858, USA

${ }^{g}$ Department of Geosciences, University of Rhode Island, Kingston, RI 02881, USA

${ }^{\mathrm{h}}$ School of Forestry and Environmental Studies, Yale University, New Haven, CT 06511, USA

${ }^{\mathrm{i}}$ School of Mathematical Sciences (Statistics), Complex Adaptive Systems Laboratory, University College Dublin, Belfield, Dublin 4, Ireland

\section{A R T I C L E I N F O}

\section{Article history:}

Received 2 July 2013

Received in revised form

19 September 2013

Accepted 26 September 2013

Available online 23 October 2013

\section{Keywords:}

Foraminifera

Salt-marsh

Transfer function

Medieval Climate Anomaly

Little Ice Age

20th Century

\begin{abstract}
A B S T R A C T
Relative sea-level changes during the last $\sim 2500$ years in New Jersey, USA were reconstructed to test if late Holocene sea level was stable or included persistent and distinctive phases of variability. Foraminifera and bulk-sediment $\delta^{13} \mathrm{C}$ values were combined to reconstruct paleomarsh elevation with decimeter precision from sequences of salt-marsh sediment at two sites using a multi-proxy approach. The additional paleoenvironmental information provided by bulk-sediment $\delta^{13} \mathrm{C}$ values reduced vertical uncertainty in the sea-level reconstruction by about one third of that estimated from foraminifera alone using a transfer function. The history of sediment deposition was constrained by a composite chronology. An age-depth model developed for each core enabled reconstruction of sea level with multi-decadal resolution. Following correction for land-level change $(1.4 \mathrm{~mm} / \mathrm{yr})$, four successive and sustained (multi-centennial) sea-level trends were objectively identified and quantified (95\% confidence interval) using error-in-variables change point analysis to account for age and sea-level uncertainties. From at least $500 \mathrm{BC}$ to $250 \mathrm{AD}$, sea-level fell at $0.11 \mathrm{~mm} / \mathrm{yr}$. The second period saw sea-level rise at $0.62 \mathrm{~mm} / \mathrm{yr}$ from $250 \mathrm{AD}$ to $733 \mathrm{AD}$. Between $733 \mathrm{AD}$ and $1850 \mathrm{AD}$, sea level fell at $0.12 \mathrm{~mm} / \mathrm{yr}$. The reconstructed rate of sea-level rise since $\sim 1850 \mathrm{AD}$ was $3.1 \mathrm{~mm} / \mathrm{yr}$ and represents the most rapid period of change for at least 2500 years. This trend began between $1830 \mathrm{AD}$ and $1873 \mathrm{AD}$. Since this change point, reconstructed sea-level rise is in agreement with regional tide-gauge records and exceeds the global average estimate for the 20th century. These positive and negative departures from background rates demonstrate that the late Holocene sea level was not stable in New Jersey.
\end{abstract}

(c) 2013 Elsevier Ltd. All rights reserved.

\section{Introduction}

Late Holocene (last $\sim 2500$ years) sea-level reconstructions with decimeter vertical and multi-decadal temporal resolution provide important information for investigating the relationships between sea-level change and temperature. Such data calibrate and test the validity of models that predict sea-level changes under scenarios of global climate evolution (e.g. Rahmstorf, 2007; Bittermann et al., 2013). Instrumental measurements of sea level (tide gauges and

\footnotetext{
* Corresponding author. +1617 6270869.

E-mail address: andrew.kemp@tufts.edu (A.C. Kemp).
}

satellites) are too short to capture pre-anthropogenic trends and the long-term (100s-1000s of years) response of sea level to temperature variations. This time-series limitation hinders the development of predictive models and is a motivation for reconstructing late Holocene sea-level changes. Proxy-temperature data show distinct climate phases during the late Holocene such as the Medieval Climate Anomaly, Little Ice Age, and 20th century warming (e.g. Moberg et al., 2005; Mann et al., 2008; Ahmed et al., 2013; Thompson et al., 2013). In contrast, relatively little is known about sea level during this period, although there is some evidence that persistent positive and negative departures from regional, linear background rates (driven primarily by glacio-isostatic adjustment; GIA) occurred prior to the onset of modern sea-level 

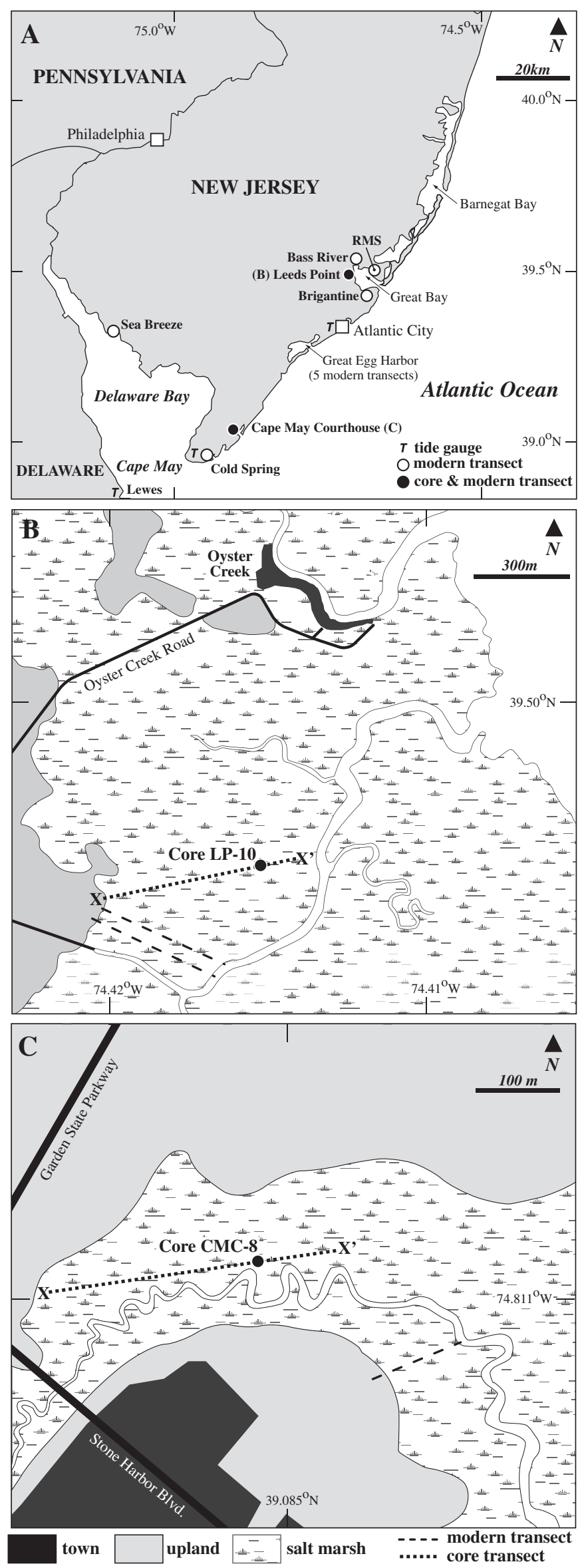

rise in the late 19th or early 20th centuries (e.g. Gehrels, 2000; van de Plassche, 2000; Sivan et al., 2004; González and Törnqvist, 2009; Kemp et al., 2011).

Salt-marsh sediment is one of the most important archives for reconstructing relative sea level (RSL) during the late Holocene. Under regimes of RSL, rise salt marshes accumulate sediment to maintain their elevation in the tidal frame (Morris et al., 2002). The resulting sequences of salt-marsh sediment accurately preserve the elevation of past RSL, which is the net result of all driving mechanisms. The vertical precision of RSL reconstructions is maximized by employing sea-level indicators that differentiate among saltmarsh sub-environments to estimate the tidal elevation where the sediment was originally deposited (paleomarsh elevation; PME). Salt-marsh foraminifera are sea-level indicators because their distribution is controlled by the frequency and duration of inundation, which is principally a function of tidal elevation (e.g. Scott and Medioli, 1978; Horton and Edwards, 2006). Foraminifera are abundant in salt marshes where they form assemblages occupying narrow elevational ranges making them suitable for quantitative and precise PME reconstructions. Bulk sediment geochemistry can also be employed as a sea-level indicator. In regions where salt marshes are dominated by $\mathrm{C}_{4}$ plants such as the mid-Atlantic and northeastern U.S., measured $\delta^{13} \mathrm{C}$ values readily identify sediment of salt-marsh origin (e.g. Middleburg et al., 1997; Wilson et al., 2005; Tanner et al., 2010). RSL reconstructions also require the timing of sediment deposition to be estimated. Sediment that accumulated under low-energy conditions on salt marshes is often undisturbed and well suited to developing detailed chronologies. Radiocarbon is the principal means to date late Holocene salt-marsh sediment, but alternatives are necessary for the period since approximately $1650 \mathrm{AD}$ because of a plateau on the calibration curve (e.g. Reimer et al., 2011). Age-depth models developed from composite chronologies incorporating radiocarbon dates and age markers of pollution and land-use change enable RSL to be reconstructed with the multi-decadal precision necessary to describe small (decimeter) RSL changes (e.g. Marshall et al., 2007). The resulting RSL reconstructions filter out short-lived (annual to decadal) sea-level variability because of the time-averaging effect of sedimentation and sampling. The resulting records are analyzed using numerical tools to identify and quantify the timing and magnitude of persistent (decadal to centennial) phases of sea-level evolution.

Relative sea-level changes in New Jersey over the past $\sim 2500$ years were reconstructed to determine how and when persistent sea-level trends deviated from background rates. Reconstructions were developed from salt-marsh sediment at two sites (Leeds Point and Cape May Courthouse; Fig. 1) using foraminifera and stable carbon isotopes $\left(\delta^{13} \mathrm{C}\right)$ as sea-level indicators and age-depth models constrained by composite chronologies of radiocarbon, ${ }^{137}$ Cs activity, and pollen and pollution chrono-horizons. Change point analysis identified four persistent periods of sea-level behavior during the last 2500 years that mark positive and negative departures from a linear background rate. The new reconstructions demonstrate that the rate of sea-level rise since $\sim 1850 \mathrm{AD}$ exceeds any previous persistent rate in the late Holocene.
Fig. 1. Location of study sites in New Jersey, USA (A). Distribution of modern foraminifera was documented at 12 sites (open circles (Kemp et al., 2013)), including five around Great Egg Harbor. Location of tide gauges at Cape May, NJ, Atlantic City, NJ, and Lewes, DE is denoted by T symbols. RMS = Rutgers Marine Station. Cores for sea-level reconstruction (filled circles) were collected at Leeds Point in the Edwin Forsythe National Wildlife Refuge (B) and at Cape May Courthouse (C). 


\section{Study area}

The New Jersey coast from Great Bay to Cape May consists of a barrier island and lagoon system separating the mainland from the Atlantic Ocean (Fig. 1). Inlets allow exchange of water between the lagoons and ocean. Great diurnal tidal ranges are smaller in the lagoons (typically $1.1 \mathrm{~m}-1.2 \mathrm{~m}$, but as small as $0.17 \mathrm{~m}$ in the upper reaches of Barnegat Bay) than on the ocean side of the barrier islands (e.g. $1.4 \mathrm{~m}$ at Atlantic City). Tidal influence extends up to $25 \mathrm{~km}$ from the coast into bays and brackish river systems such as Great Egg Harbor River. Modeling of paleotides in New Jersey indicates that great diurnal tidal range changed very little during the late Holocene, even at the scale of coastal embayments and estuaries (Horton et al., 2013).

Modern salt marshes in the study region form extensive (often more than $1 \mathrm{~km}$ wide) platforms with very gentle elevation gradients. Tidal flats are rare in New Jersey because the marsh front is usually a pronounced step change in elevation. Low-marsh settings between mean tide level (MTL) and mean high water (MHW) are typically vegetated by the $\mathrm{C}_{4}$ plant Spartina alterniflora (tall form). The high-marsh floral zone between MHW and mean higher high water (MHHW) is vegetated by Spartina patens, Distichlis spicata, and S. alterniflora (short form), all of which are $C_{4}$ plants. The transition above MHHW from high salt marsh to freshwater upland is characterized by Phragmites australis, Iva fructescens, and Baccharis halimmifolia, all of which are $C_{3}$ plants. At sites with greater freshwater influence, Typha augustifolia, and Schoenoplectus americanus ( $C_{3}$ plants) are also common (Stuckey and Gould, 2000). Salt marshes are replaced upstream by brackish marshes dominated by $P$. australis, T. augustifolia, $S$. americanus ( $C_{3}$ plants) and the $C_{4}$ plant Spartina cynosuroides (Tiner, 1985). Examples of these environments are found on the Great Egg Harbor River (Fig. 1).

Several distinctive assemblages of foraminifera exist of modern salt marshes in New Jersey (Kemp et al., 2012a, 2013). The dominant species in low-marsh environments are Miliammina fusca and Ammobaculites spp. High-marsh environments are populated by at least five distinctive assemblages of foraminifera, including groups dominated by Jadammina macrescens, Tiphotrocha comprimata, Trochammina inflata, Arenoparrella mexicana, and Ammoastuta inepta (most prevalent in low-salinity settings). At some sites Haplophragmoides manilaensis is the dominant species in the transitional marsh zone. Foraminifera are absent from freshwater environments.

Throughout the Holocene New Jersey experienced RSL rise from eustatic rise and isostatic subsidence. RSL 8000 years before present (yrs BP) was at approximately $-12 \mathrm{~m}$, at $5000 \mathrm{yrs}$ BP it was at $-9 \mathrm{~m}$, and at 2000 yrs BP it was at $-4 \mathrm{~m}$ (Miller et al., 2009; Engelhart and Horton, 2012; Horton et al., 2013). During the late Holocene, the primary driver of RSL change in New Jersey was glacio-isostatic subsidence caused by retreat and collapse of the Laurentide Ice Sheet's forebulge at a rate of approximately $1.4 \mathrm{~mm} /$ yr (Engelhart et al., 2009, 2011b). As RSL rose, sediment deposited in back-barrier settings (including salt-marsh peat and estuarine muds) formed sedimentary archives from which RSL changes can be reconstructed (Daddario, 1961; Meyerson, 1972; Psuty, 1986). Instrumental measurements of RSL in New Jersey are available since 1911 AD when the Atlantic City tide gauge was installed. The Sandy Hook tide gauge began measurements in 1932 AD, while the tide gauges at Cape May and Lewes (Delaware) provide data since $1966 \mathrm{AD}$ and $1919 \mathrm{AD}$ respectively. The linear rate of RSL rise (to $2012 \mathrm{AD}$ ) is $4.10 \mathrm{~mm} / \mathrm{yr}$ at Atlantic City, $4.06 \mathrm{~mm} / \mathrm{yr}$ at Sandy Hook, $4.64 \mathrm{~mm} / \mathrm{yr}$ at Cape May, and $3.39 \mathrm{~mm} / \mathrm{yr}$ at Lewes (Delaware; Fig. 1a).

The Leeds Point and Cape May Courthouse sites were selected after coring at numerous locations in southern New Jersey demonstrated that they had long and/or uninterrupted accumulations of salt-marsh sediment suitable for reconstructing late Holocene RSL. Leeds Point is located in the Edwin Forsythe National Wildlife Refuge on the west side of Great Bay (Fig. 1a, b), in an area where salt marshes frequently exceed $1 \mathrm{~km}$ in width (Ferland, 1990). Low-marsh areas bordering tidal creeks are vegetated by $S$. alterniflora (tall form). The expansive high salt-marsh platform is characterized by S. patens with D. spicata. A narrow (10-20 m wide) brackish zone bordering the surrounding forested upland is vegetated by $P$. australis and T. augustifolia. The Leeds Point salt marsh was extensively ditched in the early 20th century for mosquito control. As a result, shallow sediment at the site is unsuitable for RSL reconstruction, but deeper material is unaffected. VDatum (Yang et al., 2008) estimated the tidal range at the Leeds Point to be $1.11 \mathrm{~m}$.

Cape May Courthouse is located on the Cape May peninsular (Fig. 1a, c). Vegetation at the site includes S. alterniflora (tall form) along the main tidal channel and smaller creeks, a high-salt marsh community of $S$. patens with $D$. spicata, and a water-logged brackish environment marking the transition between salt marsh and upland. The dominant vegetation in this zone is P. australis with $T$. augustifolia, and S. americanus. A narrow, infilled valley was investigated because it showed little evidence of human modification. The sediment underlying the Cape May Courthouse site is suitable for detailed reconstruction of recent RSL changes including the historic period. VDatum (Yang et al., 2008) estimated the tidal range at Cape May Courthouse to be $1.40 \mathrm{~m}$.

\section{Materials and methods}

\subsection{Estimating paleomarsh elevation}

At each site, multiple transects of hand cores were recovered to describe the underlying stratigraphy. The cores chosen for detailed analysis are Leeds Point core 10 (LP-10) and Cape May Courthouse core 8 (CMC-8) because they included some of the thickest sequences of high salt-marsh peat. Cores for laboratory analysis were collected using a Russian-type core to prevent compaction during sampling, sealed in plastic wrap and kept refrigerated. Samples of core material ( $1 \mathrm{~cm}$ thick) were sieved under running water to isolate and retain the foraminifera-bearing fraction between $63 \mu \mathrm{m}$ and $500 \mu \mathrm{m}$. Foraminifera were counted wet under a binocular microscope and a minimum of 100 individuals were enumerated or the entire sample was counted if $<100$ were present. Identifications were made by comparison with modern examples from the study region (Kemp et al., 2013).

A weighted averaging transfer function with inverse deshrinking (WA-inv) was applied to assemblages of foraminifera in the LP10 and $\mathrm{CMC}-8$ cores to estimate the PME at which the sample was originally deposited. A unique (sample-specific) uncertainty was generated for each sample using bootstrapping $(n=10,000)$ that represents an approximately $1 \sigma$ confidence interval for PME. This transfer function was developed (and described) by Kemp et al. (2013) from 175 modern samples of foraminifera compiled from 12 salt marshes in southern New Jersey (including Leeds Point and Cape May Courthouse) representing a range of physiographic settings (Fig. 1a). Transfer function performance was assessed using seven tests and indicated that PME could be reconstructed with an estimated uncertainty of $\pm 14 \%$ of great diurnal tidal range (MLLW to MHHW). Leave-one-site-out cross validation showed that spatial autocorrelation caused by sampling along transects was negligible (Kemp et al., 2013). Core assemblages were analyzed after squareroot transformation of population data. All taxa were retained and used in estimating PME. Reconstructions of PME from the transfer function are in standardized water level index (SWLI) units, 
which was used to combine modern assemblage data from sites with different tidal ranges (Horton and Edwards, 2006). A value of 0 corresponds to MLLW and 100 to MHHW.

To investigate the ecological plausibility of these reconstructions, dissimilarity between assemblages of foraminifera in core material and their closest modern counterpart was calculated using the Bray-Curtis metric. Thresholds for assessing the degree of analogy were established from pairwise analysis of the modern dataset (Kemp et al., 2013). Distances within the lower 20\% of dissimilarity between modern samples were treated as having acceptable analogues, within $10 \%$ as having good analogues, and within $2 \%$ as having very strong analogues. To assess how well the transfer function fits observations of elevation, goodness-of-fit statistics were calculated for core samples by passively fitting them into a constrained ordination (canonical correspondence analysis; CCA) of the modern dataset with tidal elevation as the only constraint following the approach of Simpson and Hall (2012). The squared residual length between core samples and their fitted positions on the first constrained axis was compared to residual differences in the modern dataset. Thresholds at 90\% (weak), 95\% (poor), and 99\% (very poor) were established from the modern dataset for progressively worse fits to tidal elevation. These two analyses were conducted on square-root transformed population data using the analogue package (v.0.8-2; Simpson, 2007) for R. They represent different and independent criteria for evaluating reconstructions from transfer functions. It is possible to have a close modern analogue, but a poor fit and vice versa (Birks, 1998). Samples exceeding the 20\% dissimilarity threshold and the $95 \%$ goodness-of-fit threshold were excluded from the RSL reconstruction.

The measurement of stable carbon isotopes in core material (1 $\mathrm{cm}$ thick bulk sediment) used the same sample-preparation method and instrument as the measurements made on modern salt-marsh sediment from New Jersey (Kemp et al., 2012c). Reported $\delta^{13} \mathrm{C}$ values were calculated to the Vienna Pee Dee Belemnite scale (VPDB; \%). Comparisons to standards were always within $0.1 \%$ and confirm that measured $\delta^{13} \mathrm{C}$ values are accurate. Replicate analysis of well-mixed samples indicated precision of $\pm<0.1 \%$ for $\delta^{13} \mathrm{C}$ measurements $(1 \sigma)$. Analysis of modern salt-marsh sediment in New Jersey demonstrated that bulk sediment with $\delta^{13} \mathrm{C}$ values more depleted than $-22.0 \%$ formed above MHHW, while values less depleted than $-18.9 \%$ were associated with low and high saltmarsh environments situated between MTL and MHHW (Kemp et al., 2012c). This distinction results from the photosynthetic pathways of $C_{3}$ and $C_{4}$ plants. On the mid-Atlantic and northeastern coasts of the United States (including New Jersey), elevations below MHHW are vegetated by $\mathrm{C}_{4}$ plants (e.g. Spartina spp., D. spicata), while elevations above MHHW are vegetated by $C_{3}$ plants (e.g. $P$. australis, I. fructescens). Since the dominant input to salt-marsh sediment is in-situ vegetation (Chmura and Aharon, 1995), $\delta^{13} \mathrm{C}$ values measured in bulk sediment provide a simple and reliable means to determine if a sample was deposited above or below the MHHW tidal datum (e.g. Johnson et al., 2007; Kemp et al., 2012c). All salt marshes receive a contribution to bulk sediment from allocthonous organic matter (e.g. marine phytoplankton), although it is usually a minor component of measured $\delta^{13} \mathrm{C}$ values (Lamb et al., 2006) and insufficient in most cases to influence paleoenvironmental interpretation. The difference between living plant material and bulk surface sediment similar in composition to the New Jersey cores is $<7 \%$ (Benner et al., 1991; Goñi and Thomas, 2000) and insufficient to cause mis-interpretation of dominance by $C_{3}$ or $C_{4}$ plants (e.g. Benner et al., 1987; Ember et al., 1987; Fogel et al., 1989). Empirical results indicate that there is little post-burial modification of bulk sediment $\delta^{13} \mathrm{C}$ values (Byrne et al., 2001; Malamud-Roam and Ingram, 2004). Indeed, an investigation of $\delta^{13} \mathrm{C}$ values in plants, surface sediment, and buried sediment at the Leeds Point site concluded that no systematic, post-burial shift could be discerned for bulk sediment derived from salt-marsh plants (Kemp et al., 2012c). Therefore $\delta^{13} \mathrm{C}$ values are a robust tool for distinguishing between bulk sediment that accumulated in environments dominated by $\mathrm{C}_{3}$ or $\mathrm{C}_{4}$ plants. Identification of extant surface vegetation to the species level would require complementary biogeochemical techniques such as molecular markers and isotopic discrimination (carbon and other elements) within structural compounds such as lignin or cellulose (e.g. Middleburg et al., 1997; Tanner et al., 2010; Vane et al., 2013).

To utilize all available palaeoenvironmental information and to reduce vertical uncertainity, PME was estimated for core samples by combining results from the foraminiferal transfer function and downcore measurements of $\delta^{13} \mathrm{C}$. The range of transfer function reconstructions was restricted to elevations in agreement with those estimated from measured $\delta^{13} \mathrm{C}$ values. The restricted ranges were treated as having uniform probability distributions in subsequent analysis. PME was therefore reconstructed in one of three ways:

i) For samples with a $\delta^{13} \mathrm{C}$ value more depleted than $-22 \%$, the transfer function estimate was trimmed to retain only the range above MHHW (SWLI $>100$ ) because $C_{3}$ plants were the dominant type of vegetation;

ii) For samples with a $\delta^{13} \mathrm{C}$ value less depleted than $-18.9 \%$, the transfer function estimate was trimmed to retain only the range below MHHW (SWLI $<100$ ) because $\mathrm{C}_{4}$ plants were the dominant type of vegetation;

iii) For samples with intermediate $\delta^{13} \mathrm{C}$ values $(-22.0 \%$ to $-18.9 \%$ ), and/or transfer function estimates that did not encompass MHHW, the full range of the original transfer function was retained because it was not possible to reliably determine if $C_{3}$ or $C_{4}$ plant species were the dominant type of vegetation.

\subsection{Dating and age-depth modeling}

Radiocarbon dating was performed on identifiable plant macrofossils found in growth position in the cores. Macrofossils were separated from the sediment matrix and cleaned under a microscope to remove contaminating material including adhered sediment particles and in-growing younger roots. The cleaned samples were oven-dried at $45{ }^{\circ} \mathrm{C}$ and submitted to the National Ocean Science Accelerator Mass Spectrometry (NOSAMS) facility for dating. At NOSAMS, all samples underwent standard acidbase-acid pretreatment. Reported radiocarbon ages and uncertainties (Table 1) were calibrated using the Intcal09 dataset (Reimer et al., 2011). Measured $\delta^{13} \mathrm{C}$ values for radiocarbon dates are from an aliquot of $\mathrm{CO}_{2}$ collected during sample combustion and were used to correct for natural fractionation of carbon isotopes.

Activity of ${ }^{137} \mathrm{Cs}$ in CMC-8 was measured at East Carolina University by gamma spectroscopy. Peak ${ }^{137} \mathrm{Cs}$ activity in core material identifies sediment deposited around 1963 AD when above ground testing of nuclear weapons was at its maximum (Warneke et al., 2002). Concentrations of elements ( $\mathrm{Cu}, \mathrm{Pb}, \mathrm{Zn}, \mathrm{Cd}$, and $\mathrm{Ni}$ ) and isotopic ratios $\left({ }^{206} \mathrm{~Pb}:{ }^{207} \mathrm{~Pb}\right)$ were measured at the British Geological Survey Environmental Science Centre to establish the timing of recent sediment deposition in CMC-8. Bulk samples $(1 \mathrm{~cm}$ thick) were prepared in an identical manner to that described by Vane et al. (2011) and analyzed using a quadropole ICP-MS instrument (Agilent 7500c) operated under the conditions specified in Kemp et al. (2012b). Concentrations were not normalized by grain size because in salt-marsh environments, heavy metal pollutants are 
Table 1

Radiocarbon dates from cores LP-10 and CMC-8.

\begin{tabular}{|c|c|c|c|c|c|}
\hline Core - Depth $(\mathrm{cm})$ & Sample ID & $\begin{array}{l}\text { Radiocarbon age } \\
\left({ }^{14} \mathrm{C} \text { years }\right)\end{array}$ & $\begin{array}{l}\text { Radiocarbon error } \\
\left({ }^{14} \mathrm{C} \text { years }\right)\end{array}$ & $\delta^{13} \mathrm{C}(\%, \mathrm{VPDB})$ & Dated material \\
\hline $\mathrm{LP} 10-127 \mathrm{~cm}^{\mathrm{a}}$ & OS-70446 & 319 & 13 & -12.41 & Sp \\
\hline LP10 - $135 \mathrm{~cm}$ & OS-79171 & 415 & 25 & -12.48 & Ds \\
\hline $\mathrm{LP} 10-146 \mathrm{~cm}$ & OS-79172 & 625 & 25 & -12.77 & Sp \\
\hline LP10 - $184 \mathrm{~cm}$ & OS-66518 & 950 & 30 & -13.78 & $\mathrm{Sp}$ \\
\hline LP10 - $188 \mathrm{~cm}$ & OS-79174 & 1090 & 25 & -13.42 & $\mathrm{Sp}$ \\
\hline LP10 - $198 \mathrm{~cm}$ & OS-70444 & 1188 & 30 & -13.13 & Sp \\
\hline $\mathrm{LP} 10-218 \mathrm{~cm}^{\mathrm{a}}$ & OS-70442 & 1249 & 13 & -13.89 & Sp \\
\hline LP10 - $226 \mathrm{~cm}$ & OS-79175 & 1290 & 25 & -13.88 & Ds \\
\hline LP10 - $237 \mathrm{~cm}$ & OS-79176 & 1320 & 25 & -13.86 & $\mathrm{Sp}$ \\
\hline $\mathrm{LP} 10-245 \mathrm{~cm}^{\mathrm{a}} \ddagger$ & OS-70443 & 1502 & 14 & -13.24 & $\mathrm{Sp}$ \\
\hline $\mathrm{LP} 10-268 \mathrm{~cm}^{\mathrm{a}} \ddagger$ & OS-70445 & 1541 & 14 & -14.57 & Sp \\
\hline LP10 - $282 \mathrm{~cm} \ddagger$ & OS-66514 & 1550 & 25 & -14.4 & $\mathrm{Sp}$ \\
\hline LP10 - $295 \mathrm{~cm}$ & OS-94847 & 1700 & 30 & -23.99 & Sa \\
\hline LP10 - $300 \mathrm{~cm}$ & OS-94846 & 1720 & 25 & -26.82 & Seed \\
\hline LP10 - $307 \mathrm{~cm}$ & OS-79177 & 1810 & 30 & -24.66 & Sa \\
\hline LP10 - $314 \mathrm{~cm} \ddagger$ & OS-79178 & 1750 & 30 & -26.47 & Sa \\
\hline LP10 - $327 \mathrm{~cm} \ddagger$ & OS-87528 & 1880 & 30 & -12.69 & HW \\
\hline $\mathrm{LP} 10-355 \mathrm{~cm}$ & OS-94848 & 2190 & 25 & -24.95 & $\mathrm{~Pa}$ \\
\hline LP10 - $365 \mathrm{~cm}$ & OS-87446 & 2230 & 25 & -25.02 & Sa \\
\hline LP10 - 386 cm & OS-94849 & 2210 & 35 & -26.26 & $\mathrm{~Pa}$ \\
\hline LP10 - $393 \mathrm{~cm}$ & OS-87524 & 2450 & 25 & -27.23 & HW \\
\hline CMC8 $-76 \mathrm{~cm}$ & OS-94468 & 120 & 30 & -11.15 & Ds \\
\hline CMC8 $-82 \mathrm{~cm}$ & OS-94470 & 230 & 25 & -10.97 & Ds \\
\hline CMC8 $-86 \mathrm{~cm}$ & OS-88617 & 250 & 40 & -10.07 & Ds \\
\hline CMC8 $-94 \mathrm{~cm}$ & OS-94469 & 285 & 30 & -10.47 & Ds \\
\hline $\mathrm{CMC} 8-111 \mathrm{~cm}$ & OS-88725 & 400 & 25 & -24.92 & $\mathrm{Sp}$ \\
\hline $\mathrm{CMC} 8-122 \mathrm{~cm}$ & OS-88618 & 520 & 40 & -13.82 & Ds \\
\hline CMC8 - $135 \mathrm{~cm}$ & OS-79179 & 770 & 30 & -13.45 & Ds \\
\hline CMC8 $-145 \mathrm{~cm}$ & OS-79180 & 865 & 25 & -13.61 & Ds \\
\hline $\mathrm{CMC} 8-160 \mathrm{~cm}$ & OS-88619 & 960 & 40 & -13.94 & Ds \\
\hline $\mathrm{CMC} 8-171 \mathrm{~cm}$ & OS-79181 & 1100 & 30 & -13.50 & Ds \\
\hline CMC8 $-180 \mathrm{~cm}$ & OS-94471 & 1120 & 25 & -12.60 & Ds \\
\hline CMC8 - $194 \mathrm{~cm}$ & OS-88620 & 1190 & 35 & -11.40 & Sp \\
\hline CMC8 - $208 \mathrm{~cm}$ & OS-88726 & 1350 & 30 & -27.73 & Sa \\
\hline
\end{tabular}

All samples were dated by the National Oceanic Sciences Accelerator Mass Spectrometry facility, sample identifiers correspond to this lab.

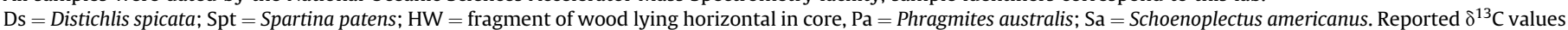
are from an aliquot of $\mathrm{CO}_{2}$ collected during sample combustion and refer only to the dated macrofossil and not the bulk sediment matrix from which it was isolated.

Samples marked with $\ddagger$ were previously published in (Kemp et al., 2012c).

a denote dates that are not reported following standard rounding of radiocarbon age and error.

more strongly associated with organic content (Vane et al., 2009), which was high (30-40\% by weight) and relatively uniform in the upper section of core CMC-8. Normalization is an appropriate step for comparing concentrations among sites, but it was not necessary for identifying trends within a single core. Downcore trends in absolute elemental concentration and their stratigraphic position were matched to features of historic production and consumption. Interpretation of the $\mathrm{Pb}$ and ${ }^{206} \mathrm{~Pb}:{ }^{207} \mathrm{~Pb}$ profiles in CMC-8 followed the approaches described in similar studies (e.g. Lima et al., 2005; Kemp et al., 2012b; Gobeil et al., 2013). In addition, the downcore $\mathrm{Zn}$ profile was compared to regional production records to recognize the onset (1880-1900 AD) and peak (1943-1969 AD) of industrial output (Bleiwas and DiFrancesco, 2010). National production records from the United States Geological Survey Minerals Yearbook also enabled recognition of peaks in Cd (1956$1969 \mathrm{AD})$ and $\mathrm{Ni}$ (1950-1980 AD; 1992-2002 AD) and the onset of $\mathrm{Cu}$ pollution (1890-1910 AD). Changes in production and consumption were assumed to have caused a corresponding change in elemental emissions that were transported through the atmosphere by constant prevailing wind patterns and deposited on the salt-marsh surface within a few years (Graney et al., 1995; Bollhöfer and Rosman, 2001) and without isotopic fractionation (Ault et al., 1970). Since emissions per unit of production or consumption changed through time, trends rather than absolute values were the basis for recognizing these features in core CMC-8. Comparison of independent chronologies developed using markers of industrial pollution and radiometric decay of ${ }^{210} \mathrm{~Pb}$ activity elsewhere in New Jersey indicated that heavy metal pollution is synchronous with industrial activity within the age and sample thickness uncertainties assigned to each marker (Kemp et al., 2012b).

Palynomorphs (pollen and fern spores) were isolated from $1 \mathrm{~cm}$ thick sediment slices of core CMC-8 using standard palynological preparation techniques (Traverse, 2007). At least 300 pollen grains and spores were counted from each sample to determine percent abundance. The rise of Ambrosia in southern New Jersey was estimated to be $1710 \mathrm{AD} \pm 50$ years based on histories of European arrival and colonization of the region. The areas around Leeds Point and Cape May Courthouse were first settled between 1695 AD and 1725 AD (Wacker, 1975; Wacker and Clemens, 1994).

Discrete dated samples were used to generate separate accumulation histories for LP-10 and CMC-8 using the Bchron package (v.3.1.5; Haslett and Parnell, 2008; Parnell et al., 2008) executed in R. Excess ${ }^{210} \mathrm{~Pb}$ was measured in CMC-8, but it was excluded from the age-depth model because the age estimates for individual samples would be treated independently by Bchron. Since ${ }^{210} \mathrm{~Pb}$ accumulation histories are modeled, the resulting suite of downcore age estimates are not independent of one another and would cause the Bchron age-depth model to be weighted (and unfairly biased) toward ${ }^{210} \mathrm{~Pb}$ results. Chronohorizons associated with ${ }^{137} \mathrm{Cs}$, pollution markers, and pollen were treated as having uniform probability distributions. Bchron is a Bayesian model for sampling age-depth chronologies that are consistent with the 
supplied age information. The models weights the contribution of the dates with that of prior assumptions about the number of outliers and the nature of physical sedimentation. Bchron uses Markov Chain Monte Carlo simulation to produce posterior chronological samples, each of which is equi-probable. The nature of the algorithm is such that starting values for the estimated chronologies are likely to be poor, so early values in the algorithm are discarded during a burn-in phase. We follow the Bchron recommendations for a long run which provides a suite of 200,000 chronologies that are then summarized to give estimates of age with a $95 \%$ uncertainty interval for every $1 \mathrm{~cm}$ thick interval in the cores. These age estimates and their associated uncertainties were applied to all samples with reconstructed PME.

\subsection{Reconstructing relative sea level and identifying persistent sea- level trends}

Relative sea level was reconstructed by subtracting the estimated PME for each sample from the measured elevation at which the sample was recovered (depth in core), where both values were expressed relative to mean tide level (MTL). Core top elevations were established using real time kinematic (RTK) satellite navigation with conversion from orthometric to tidal datums using VDatum (v2.3.5, New Jersey coastal embayment dataset v1). Core LP-10 is at $0.56 \mathrm{~m}$ MTL and core CMC- 8 is at $0.53 \mathrm{~m}$ MTL. The vertical uncertainty of the reconstruction is the range from the transfer function that was amended by $\delta^{13} \mathrm{C}$ values. The age (with associated range) of each core sample was taken directly from the age-depth model. RSL data are presented as boxes, where the height represents sea-level error and the width is age error. RSL data are provided in appendix A.

Following adjustment for the estimated rate of land subsidence in New Jersey, the independent reconstructions from Leeds Point and Cape May Courthouse were combined into a single dataset and reordered by age. The combined record has the advantage over analyzing two individual records of spanning all of the last 2500 years. Proxy reconstructions are characterized by age and sea-level errors that are unique to each sample and an uneven distribution of samples in time. Simple linear regression is therefore an unsuitable method of analysis since it assumes that the explanatory variable $(x$, in this case age) is fixed and known. Therefore change point analysis was used to identify periods of persistent sea-level variability in New Jersey during the late Holocene and estimated the timing of change points and the rate of sea-level rise between them with 95\% confidence. An extension of the error-in-variables (EIV) model was applied to proxy reconstructions because it accounts for both age and sea-level uncertainties (Spiegelhalter et al., 2002).

The simplest EIV model can be written as

$y_{i}=\alpha+\beta \mu_{x i}+\varepsilon_{i}$

where $y_{i}$ is sea level for the $i$ th observation, $\alpha$ is the intercept, $\beta$ is the rate of sea-level change, and $\mu_{x i}$ is the unknown age for the $i$ th observation. Since ages in paleoenvironmental reconstructions have uncertainty, they are treated as an unknown random variable to be estimated. The term $\varepsilon_{i}$ is residual term for the $i$ th observation that incorporates the uncertainty for each sea-level reconstruction which is fixed and known and also an unknown error that was not included in the measurement error. Therefore $\varepsilon_{i} \sim N\left(0, \sigma_{y i}^{2}+\tau^{2}\right)$, and $x_{i}=\mu_{x i}+\delta_{i}$, and $\delta_{i} \sim N\left(0, \sigma_{x i}^{2}\right)$.

The terms $\sigma_{y i}^{2}$ and $\sigma_{x i}^{2}$ are the variances of sea level and age respectively. The variance parameter $\left(\tau^{2}\right)$ represents the variance of the unknown error in the dataset. The model assumes that $x_{i}$ and $y_{i}$ follow the bivariate normal distribution shown below where $x_{i}$ is sample age and $y_{i}$ is reconstructed sea level for samples $i$ to $n$. $\left(\begin{array}{l}x_{i} \\ y_{i}\end{array}\right) \sim N\left(\left(\begin{array}{l}\mu_{x i} \\ \mu_{y i}\end{array}\right),\left(\begin{array}{cc}\sigma_{x i}^{2} & \sigma_{x i, y i} \\ \sigma_{x i, y i} & \sigma_{y i}^{2}\end{array}\right)\right)$

The term $\sigma_{x i y i}$ is the covriance between the individual age and sea-level reconstructions that arises as a result of correcting for GIA. With a single change point it is assumed that the data follow one EIV model before the change point, where $\mu_{y i} \sim N\left(\alpha+\beta_{1}\left(x_{i}-x_{\text {change }}\right), \tau^{2}\right)$, and another EIV model afterward, where $\mu_{y i} \sim N\left(\alpha+\beta_{2}\left(x_{i}-x_{\text {change }}\right), \tau^{2}\right)$. The parameter $x_{\text {change }}$ represents the age at which the sea-level rate changes significantly, and the parameters $\beta_{1}$ and $\beta_{2}$ are the rate before and after the change point, respectively. For the New Jersey sea-level reconstruction, the model was extended to include one to four change points. Since the data are corrected for the contribution of land-level changes, the covariance matrix for the EIV model accounts for the distortion of data points from rectangles to parallelograms and the angle of the parallelogram (i.e. the rate of land-level change). The model that best describes the data was selected using the deviance information criterion (DIC; Spiegelhalter et al., 2002), which is a Bayesian method for model comparison, where the posterior distribution was obtained by Markov Chain Monte Carlo simulation. Deviance is a measure of distance between the data (reconstructed sea level) and model predictions. More complex models will almost always have lower deviance and are consequently penalized relative to the number of unconstrained parameters in the model. DIC accounts for both mean deviance and also complexity to ensure that model selection is fair and unbiased. Models with lower DIC are preferable to those with larger DIC.

\section{Results}

\subsection{Foraminifera and $\delta^{13} \mathrm{C}$ values in cores from Leeds Point (LP-10) and Cape May Courthouse (CMC-8)}

To establish the environment and elevation of sediment deposition, foraminifera were counted in core samples positioned at regular intervals, dated levels, and to capture transitions between assemblage types and stratigraphic units. The lowest occurrence of foraminifera in LP-10 was at $3.95 \mathrm{~m}$ (Fig. 2). Between $3.95 \mathrm{~m}$ and $2.85 \mathrm{~m}$ the most common foraminifera was J. macrescens that occurred with $T$. comprimata and $T$. inflata. The interval between $3.13 \mathrm{~m}$ and $3.00 \mathrm{~m}$ was characterized by an unusually high abundance of Miliammina petila (24-60\%), while the low-marsh species M. fusca was common (>20\%) from $2.82 \mathrm{~m}$ to $2.95 \mathrm{~m}$. T. inflata was the dominant species of foraminifera from $2.82 \mathrm{~m}$ to $1.85 \mathrm{~m}$. Foraminifera were absent between $1.85 \mathrm{~m}$ and $1.73 \mathrm{~m}$ The uppermost section of LP-10 (1.73 m-1.20 m) was comprised of a near mono-specific assemblage of $J$. macrescens. Foraminifera were present in the top $1.20 \mathrm{~m}$ of LP-10, but were not analyzed in detail because this material was unsuitable for sea-level reconstruction due to human modification. Foraminifera throughout core LP-10 indicate deposition in a high salt-marsh environment.

Measurements of $\delta^{13} \mathrm{C}$ values were made on bulk sediment in LP10 at regularly spaced intervals to establish the botanical and environmental origin of core samples. At depths between $4.20 \mathrm{~m}$ and $3.31 \mathrm{~m} \delta^{13} \mathrm{C}$ values varied from $-27.0 \%$ to $-22.2 \%$ (Fig. 2 ), which is characteristic of an environment dominated by $C_{3}$ plants such as those in the transition between salt marsh and freshwater upland communities. This sedimentary unit was a black, amorphous organic unit. The interval between $3.26 \mathrm{~m}$ and $2.86 \mathrm{~m}$ included some $\delta^{13} \mathrm{C}$ values $(-21.4 \%$ to $-19.1 \%$ ) that are intermediate between those of modern $C_{3}$ and $C_{4}$ plants. Measured $\delta^{13} \mathrm{C}$ values in the upper $2.81 \mathrm{~m}$ of $\mathrm{LP}-10$ varied from $-16.8 \%$ to $-13.1 \%$ and were typical of a salt-marsh environment vegetated by $\mathrm{C}_{4}$ plants. These $\delta^{13} \mathrm{C}$ values 


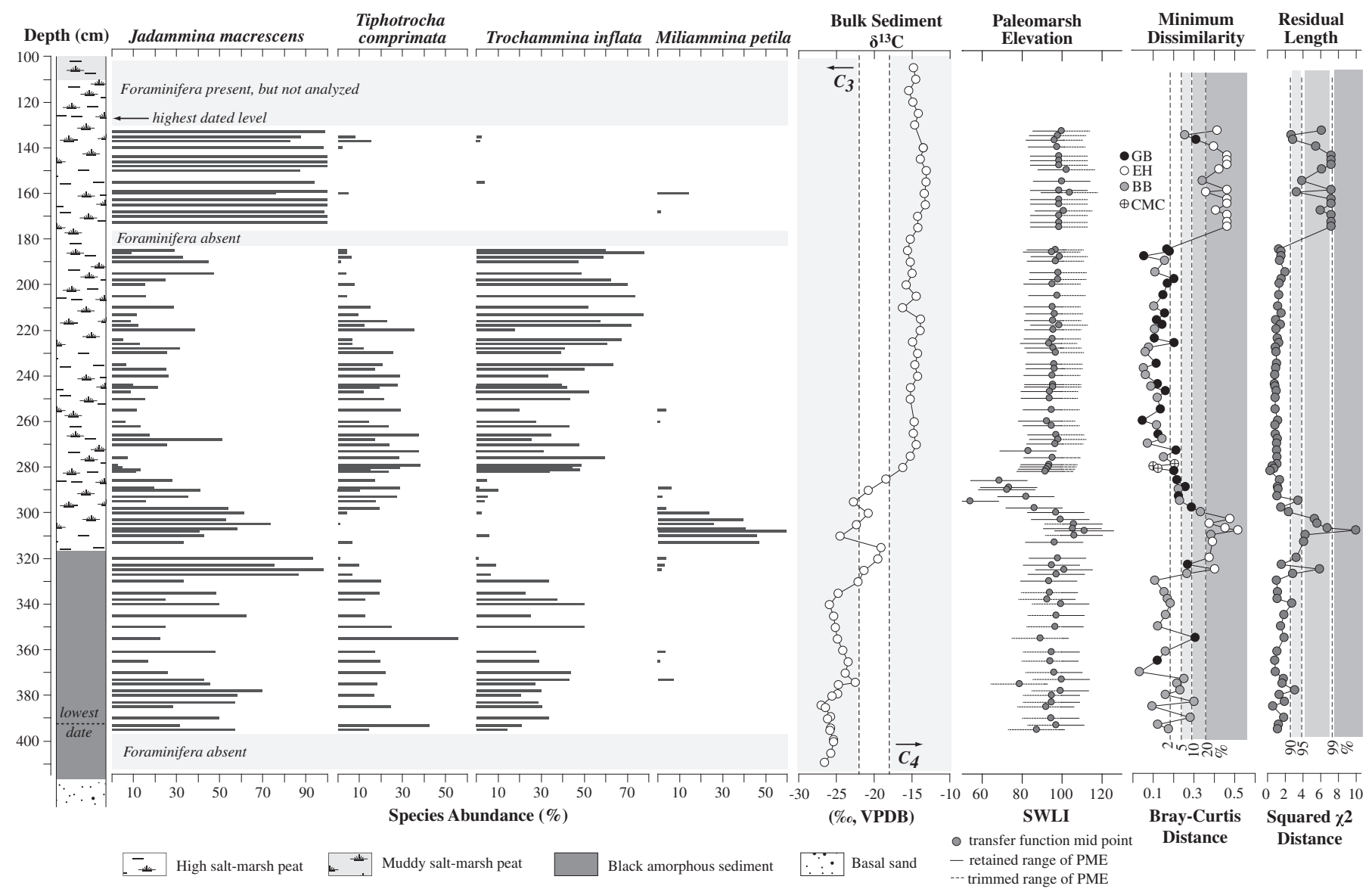

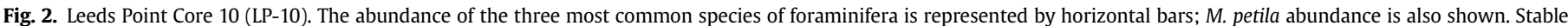

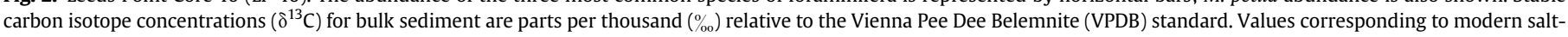

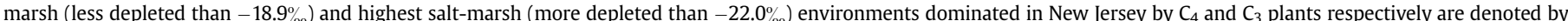

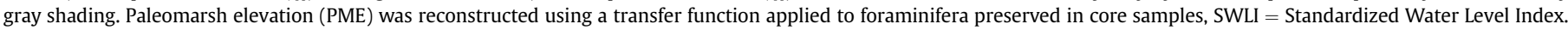

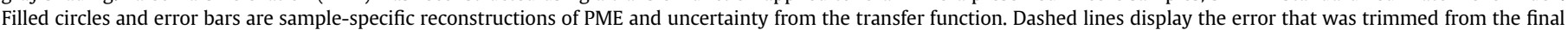

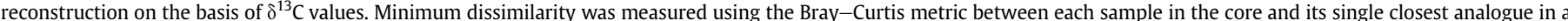

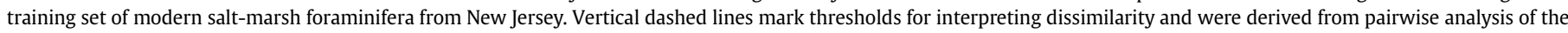

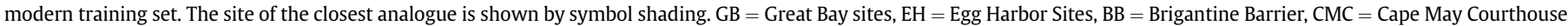

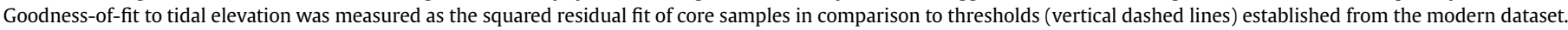

indicate that the section of LP-10 that was devoid of foraminifera $(1.85 \mathrm{~m}-1.73 \mathrm{~m})$ formed in a salt-marsh environment.

Foraminifera were present in core CMC-8 to a depth of $2.22 \mathrm{~m}$, but below $1.72 \mathrm{~m}$ there were few individuals and these sparse assemblages were not considered suitable for quantitative analysis (Fig. 3). From $1.72 \mathrm{~m}$ to $1.29 \mathrm{~m}$, assemblages were largely composed of $J$. macrescens and T. inflata. Foraminifera were absent between $1.25 \mathrm{~m}$ and $1.12 \mathrm{~m}$. The dominant species from $1.10 \mathrm{~m}$ to $0.33 \mathrm{~m}$ was $J$. macrescens, while samples from $0.31 \mathrm{~m}$ to $0.05 \mathrm{~m}$ had assemblages of T. inflata, T. comprimata and J. macrescens. These assemblages demonstrate that core CMC-8 accumulated in a high saltmarsh environment. The two uppermost samples $(0.03 \mathrm{~m}$ and $0.05 \mathrm{~m}$ ) had an assemblage that included $17 \%$ and $21 \% \mathrm{M}$. fusca respectively. In core CMC- 8 , bulk sediment between $2.58 \mathrm{~m}$ and $1.85 \mathrm{~m}$ had $\delta^{13} \mathrm{C}$ values between $-28.6 \%$ and $-22.1 \%$ (Fig. 3 ), which is typical of an environment dominated by organic inputs from $C_{3}$ plants. This sedimentary unit was a black, amorphous organic unit. The uppermost $1.78 \mathrm{~m}$ of the core included samples with $\delta^{13} \mathrm{C}$ values from $-18.9 \%$ to $-13.1 \%$, which fall within the range of modern salt marshes dominated by $\mathrm{C}_{4}$ plants in New Jersey. This indicates that sediment in the interval devoid of foraminifera $(1.25 \mathrm{~m}-1.12 \mathrm{~m})$ formed in a salt marsh. A single sample at $1.81 \mathrm{~m}$ had an intermediate value of $-20.3 \%$.

\subsection{Transfer function application and evaluation}

To reconstruct paleomarsh elevation, the regional weightedaveraging transfer function with inverse deshrinking (WA-inv) of Kemp et al. (2013) was applied to assemblages of foraminifera enumerated from cores LP-10 and CMC-8 (Figs. 2 and 3). The transfer function estimated PME and an uncertainty (in SWLI units) derived by bootstrapping that is unique to each sample. In LP-10, transfer function estimates of PME ranged from 54 to 111 SWLI units (average 95) with an average uncertainty of \pm 14 SWLI units (equating to $\pm 0.15 \mathrm{~m}$ at this site). Samples with high abundances of M. petila between $3.10 \mathrm{~m}$ and $3.00 \mathrm{~m}$ had slightly above average reconstructed PMEs (average 104 SWLI units), while the eight samples in which the low-marsh foraminifera $M$. fusca made up more than $20 \%$ of the assemblage $(2.98 \mathrm{~m}-2.82 \mathrm{~m})$ had correspondingly lower PME (average 75 SWLI units). PME estimated by the transfer function for samples in CMC-8 reflects the dominance of high-marsh species of foraminifera (J. macrescens, T. inflata and T. comprimata) throughout the core. The average PME was 97 SWLI units with an uncertainty of \pm 14 SWLI units (equating to $\pm 0.20 \mathrm{~m}$ at this site). The two samples near the top of the core with increased $M$. fusca formed at a slightly lower PME (86-88 SWLI). Transfer function reconstructions of PME were modified on the 


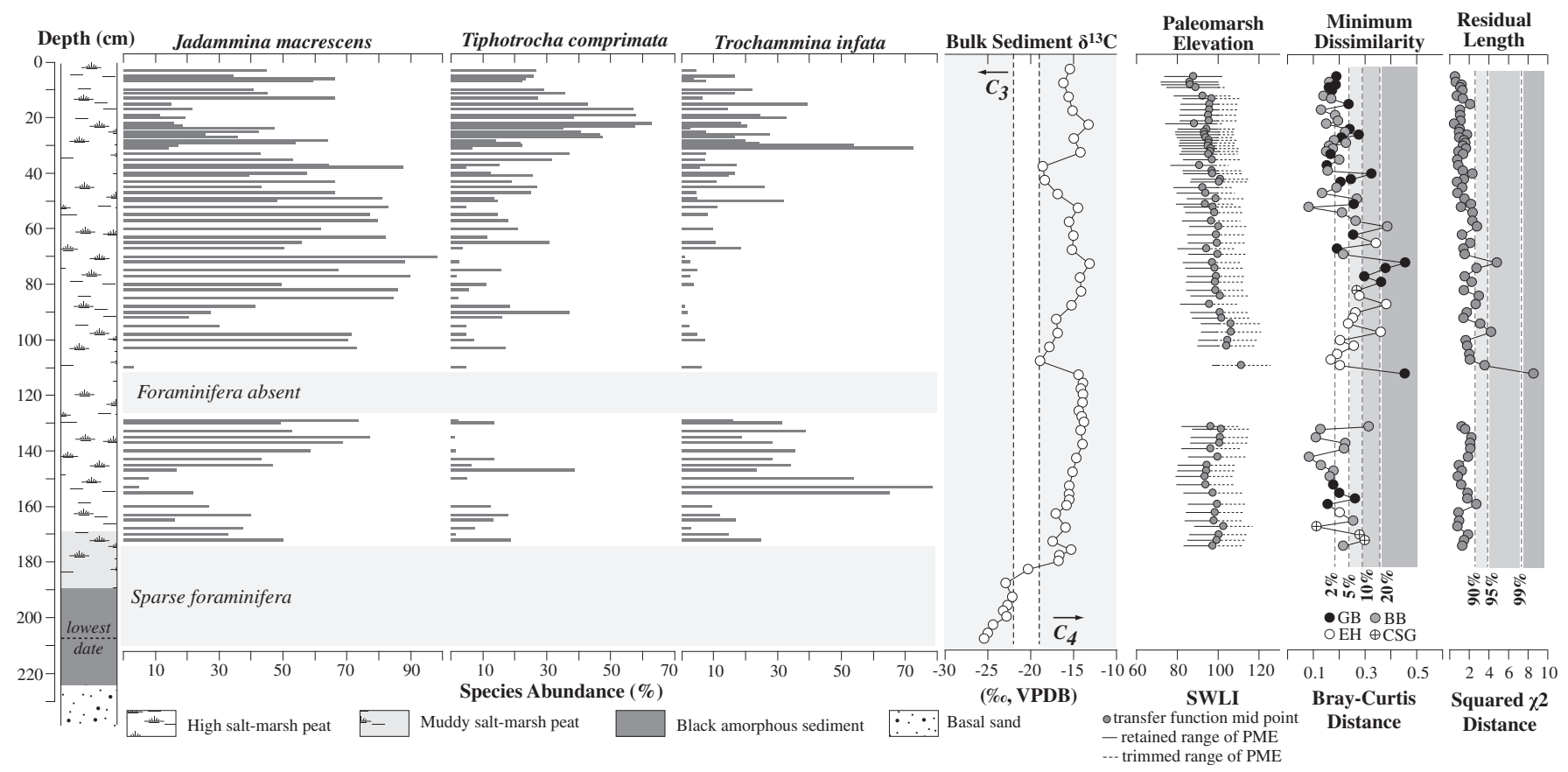

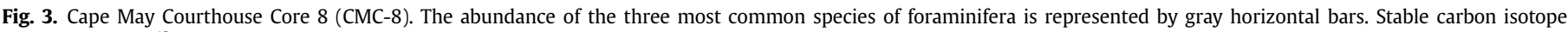

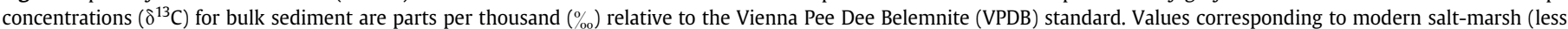

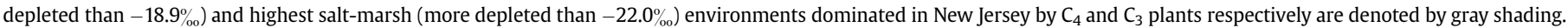

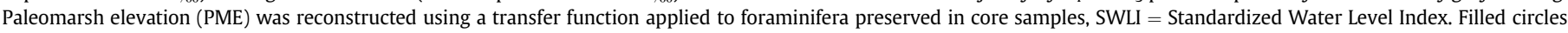

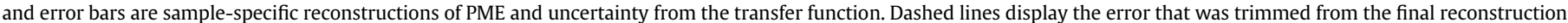

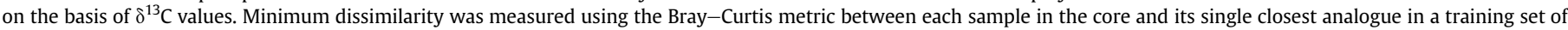

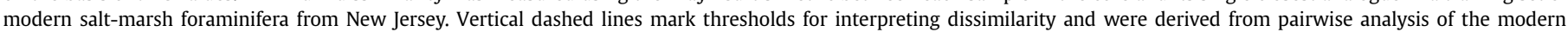

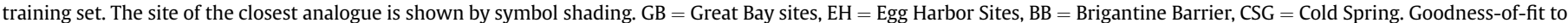
tidal elevation was measured as the squared residual fit of core samples in comparison to thresholds (vertical dashed lines) established from the modern dataset.

basis of bulk sediment $\delta^{13} \mathrm{C}$ values to identify samples that formed above or below the MHHW tidal datum as identified by the dominance of either $C_{3}$ (above MHHW) or $C_{4}$ plants (below MHHW). Across both cores, $86 \%$ of samples were modified following this approach. The remaining, untrimmed samples either returned transfer-function estimates of PME that did not include MHHW within their uncertainty, or had intermediate $\delta^{13} \mathrm{C}$ values between those of $C_{3}$ and $C_{4}$ plants. The average reduction in vertical uncertainty was approximately 5.5 SWLI units, equating to about one third of the original transfer function estimate (Figs. 2 and 3).

To judge ecological plausibility of transfer function results, the measured dissimilarity between core samples and their closest modern counterpart was compared to thresholds established by pairwise comparison of the modern training set. In LP-10, 74 samples were within the 20th percentile threshold for an acceptable modern analogue that was established from pairwise analysis of the training set (Fig. 2). Twenty two samples exceeded this threshold, including most samples above $1.75 \mathrm{~m}$ that were comprised of near-monospecific assemblages of $J$. macrescens. These samples lacked a modern analogue because J. macrescens had a maximum abundance of $62 \%$ in the modern training set. The samples exceeding the 20th percentile threshold between $3.03 \mathrm{~m}$ and $3.25 \mathrm{~m}$ included abundances of $M$. petila that exceed its maximum contribution to any modern sample (19\%). In CMC-8, seven samples had a minimum dissimilarity exceeding the 20th percentile because they included abundances of $J$. macrescens greater than any sample in the modern training set (Fig. 3).

The validity of elevation reconstructions was judged using goodness-of-fit statistics where core samples were positioned passively on the ordination of modern samples and residual fits were compared to thresholds for weak (90\%), poor (95\%), or very poor (99\%) fits. In LP-10, 23 samples exceeded the 95\% threshold established for a poor or very poor fit (Fig. 2). These samples were associated with the interval where $M$. petila was abundant and also in the uppermost $1.72 \mathrm{~m}$ where J. macrescens formed near monospecific assemblages. In most cases, samples with large residual lengths were also dissimilar to modern samples in their faunal composition. In CMC-8, three samples surpassed the 95\% threshold for a poor or very poor fit (Fig. 3). Core samples that lacked a modern analogue ( $>20 \%$ threshold for dissimilarity) and had a poor or very poor fit to tidal elevation ( $>95 \%$ threshold for goodness-offit) were excluded from the RSL reconstruction and further analysis.

\subsection{Core chronologies}

The Leeds Point and Cape May Courthouse sites experienced sediment accumulation for the period under consideration as a result of RSL rise. In LP-10, 21 radiocarbon dates on identifiable plant macrofossils show that accumulation of organic sediment began at approximately 600 BC (Fig. 4; Table 1). The Bchron age-depth model was developed using all 21 radiocarbon dates and estimated the age of each $1 \mathrm{~cm}$ thick interval in LP-10 with a unique uncertainty that ranged from \pm 17 years to \pm 113 years (average of \pm 50 years). From the lowest dated level (3.93 m; approximately $580 \mathrm{BC}$ ) to the radiocarbon date at $3.14 \mathrm{~m}$ (approximately $286 \mathrm{AD}$ ), the average rate of sediment accumulation was $0.9 \mathrm{~mm} / \mathrm{yr}$. From $286 \mathrm{AD}$ to $1344 \mathrm{AD}$, the average rate of sediment accumulation in LP-10 was $1.6 \mathrm{~mm} / \mathrm{yr}$ and from $1344 \mathrm{AD}$ to $1570 \mathrm{AD}$ it averaged $0.8 \mathrm{~mm} / \mathrm{yr}$.

To provide a decadal chronology for the period since $\sim 1650 \mathrm{AD}$ that is affected by the radiocarbon plateau, the upper $0.70 \mathrm{~m}$ of core CMC-8 was dated by identifying chronohorizons from changes in pollen (Ambrosia), concentrations of $\mathrm{Pb}, \mathrm{Zn}, \mathrm{Cu}, \mathrm{Cd}$, and $\mathrm{Ni},{ }^{137} \mathrm{Cs}$ 


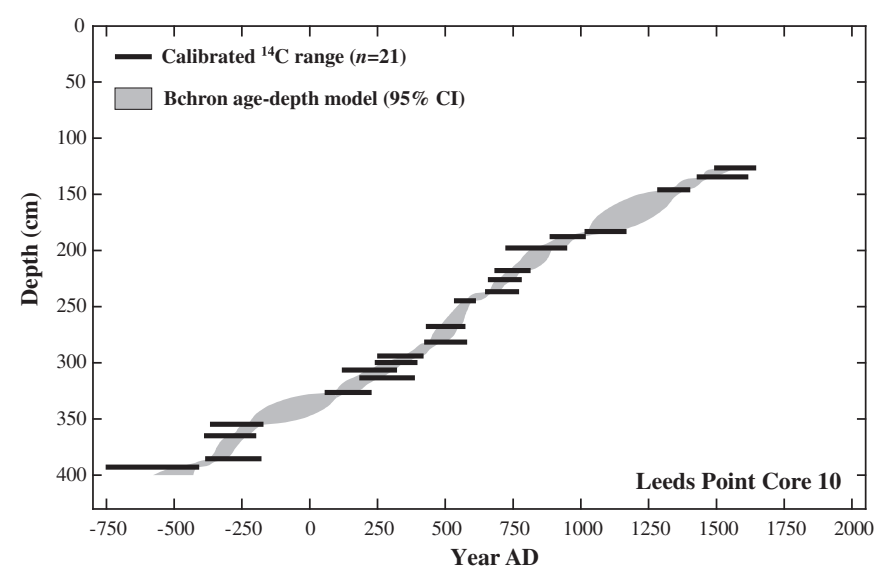

Fig. 4. Chronology developed for core LP-10. Twenty one, identifiable plant macrofossils were radiocarbon dated and constrained the Bchron age model (shaded gray envelope). Solid horizontal bars represent the full range of calibrated ages rather than their probability distribution.

activity, and shifts in the isotopic ratio of ${ }^{206} \mathrm{~Pb}:{ }^{207} \mathrm{~Pb}$ (Fig. 5). These downcore changes were related to historic events such as widespread land clearance by European settlers and trends in national and regional industrial production. In addition to these age estimates, 13 radiocarbon dates constrain the timing of sediment deposition from $0.76 \mathrm{~m}$ to $2.08 \mathrm{~m}$ (Fig. 6). Accumulation of organic material at the core site began at around $700 \mathrm{AD}$ and continued without interruption to the present day. All chronological data provided constrains for the Bchron (Parnell et al., 2008) age-depth model that estimated the age of each $1 \mathrm{~cm}$ interval in the core with errors ranging from \pm 1.5 years to \pm 58 years (average \pm 28.5 years). The average rate of sediment accumulation in CMC- 8 between $700 \mathrm{AD}$ and $1850 \mathrm{AD}$ was approximately $1.3 \mathrm{~mm} / \mathrm{yr}$, after which it increased to $3.9 \mathrm{~mm} / \mathrm{yr}$ (Fig. 6).

\section{Sea level change in New Jersey}

The New Jersey RSL reconstruction is represented by boxes that incorporate sea-level and age uncertainty (Fig. 7). RSL in New Jersey was $-4.20 \mathrm{~m}$ at approximately $500 \mathrm{BC}$ and rose to $-0.70 \mathrm{~m}$ at around 1850 AD. Agreement between the RSL reconstructions from Cape May Courthouse and Leeds Point between $970 \mathrm{AD}$ and $1460 \mathrm{AD}$ indicates that local-scale processes were not the dominant drivers of RSL in New Jersey, at least for that shared interval. The RSL reconstruction lies within the uncertainties of basal reconstructions compiled for New Jersey (Fig. 7a) indicating a lack of detectable compaction. Furthermore, the overlap and coherence of the reconstructions from Leeds Point and Cape May Courthouse (which have different sediment thicknesses and compositions) indicates that compaction did not make a significant contribution to reconstructed RSL trends, likely because the saturated, low density nature of salt-marsh peat makes it resistant to compaction (e.g. Brain et al., 2012). Similarly, annual RSL measurements from tide gauges at Atlantic City, Sandy Hook, Cape May, and Lewes display a high degree of coherence, demonstrating that local processes were not the dominant drivers of historical RSL change in New Jersey (Fig. 8a). A regional tide-gauge record generated by averaging the four gauges shows approximately $0.37 \mathrm{~m}$ of RSL rise in New Jersey since $1911 \mathrm{AD}$ at an average rate of $4.03 \mathrm{~mm} / \mathrm{yr}$ (Fig. 8b). During the 20th century, RSL rise reconstructed from salt-marsh sediment was approximately $0.4 \mathrm{~m}$. The averaged tide-gauge measurements lie within the age and vertical uncertainties of the RSL reconstruction and give confidence that the reconstruction is an accurate representation of long-term, persistent RSL changes in New Jersey.
Measurements and reconstructions of RSL are the net result of multiple processes that often act simultaneously. To allow comparisons among regions and to identify climate-related sea-level trends, it is necessary to estimate and remove the contribution made by land-level changes. The principal mechanism for regional land-level change in coastal New Jersey during the late Holocene was GIA from collapse and retreat of the Laurentide Ice Sheet's proglacial forebulge (Engelhart et al., 2011b). The ICE6G-VM5b Earth-Ice model predicts RSL being $2.13 \mathrm{~m}$ below present at 2000 yrs BP at Cape May Courthouse and Leeds Point (Engelhart et al., 2011b). Eustatic input ceases at 4000 yrs BP in this model, since then all RSL changes $(1.1 \mathrm{~mm} / \mathrm{yr})$ are attributed to GIA and associated processes such as redistribution of water in response to changes in the geoid. However, the total contribution of land-level change also includes tectonic processes and regional sediment consolidation. Total land-level change was estimated from a regional compilation of basal RSL reconstructions (Engelhart et al., 2009). This approach fits a linear regression to late Holocene, basal, sea-level index points (up to $1900 \mathrm{AD}$ ) and like the Earth-Ice model assumes there was no eustatic contribution, meaning that the RSL trend approximates the net effect of all land-level changes including processes other than GIA (Shennan et al., 2012). For New Jersey, the estimated rate of land-level change is subsidence of $1.4 \mathrm{~mm} / \mathrm{yr}$ (Engelhart et al., 2011b). The difference $(0.3 \mathrm{~mm} / \mathrm{yr})$ in rates estimated from the Earth-Ice model and database of sea-level index points could be from land-level change caused by non-GIA processes or a misfit in model parameters. Earth-Ice models and compilations of RSL reconstructions demonstrate that estimating land-level change using a linear rate is appropriate for the timescale under consideration.

It is widely assumed that late Holocene sea level was stable at multi-decadal to multi-centennial timescales until the onset of modern rates of rise in the late 19th or early 20th century (Bindoff et al., 2007; Church et al., 2008; Cronin, 2012). The annual to decadal variability that is apparent in tide-gauge records must also have characterized the late Holocene. Given the attribution of 20th century sea-level rise to global climate change (e.g. Rahmstorf, 2007), it is reasonable to expect phases of sea-level behavior within the late Holocene related to known phases of warmer (e.g. Medieval Climate Anomaly) and cooler (e.g. Little Ice Age) temperatures. To challenge the assumption of stability it is necessary to reconstruct sea level through the full late Holocene period with accuracy and precision that enables confident identification of relatively small and relatively short lived sea-level changes. Therefore the New Jersey reconstruction represents a suitable dataset for identifying regional departures from late Holocene stability after correction for land-level changes. After subtracting $1.4 \mathrm{~mm} / \mathrm{yr}$ of land-level change from the RSL reconstructions three change points were identified using the EIV model (Fig. 9). Models with fewer, or more than, three change points were inferior because they had larger DIC values (Table 2). The three change points therefore define four periods of persistent (centennial) sealevel trends. From at least $500 \mathrm{BC}$ to $250 \mathrm{AD}$, sea level fell at a mean rate of $0.11 \mathrm{~mm} / \mathrm{yr}$. The second period saw sea-level rise at a mean rate of $0.62 \mathrm{~mm} / \mathrm{yr}$ from $250 \mathrm{AD}$ to $733 \mathrm{AD}$. Between $733 \mathrm{AD}$ and $1850 \mathrm{AD}$, sea level fell at a mean rate of $0.12 \mathrm{~mm} / \mathrm{yr}$. Since $1850 \mathrm{AD}$ the reconstructed rate of sea-level rise was $3.1 \mathrm{~mm} / \mathrm{yr}$. Late Holocene sea-level changes in New Jersey include distinct positive and negative departures from background rates and demonstrate that the assumption of sea-level stability (in this region at least) is unjustified.

The most prominent feature in the New Jersey sea-level reconstruction is the inflection that marks the initiation of modern rates of sea-level rise between $1830 \mathrm{AD}$ and $1873 \mathrm{AD}$ (Table 2; Fig. 9a). Using a global compilation of tide-gauge records Church 


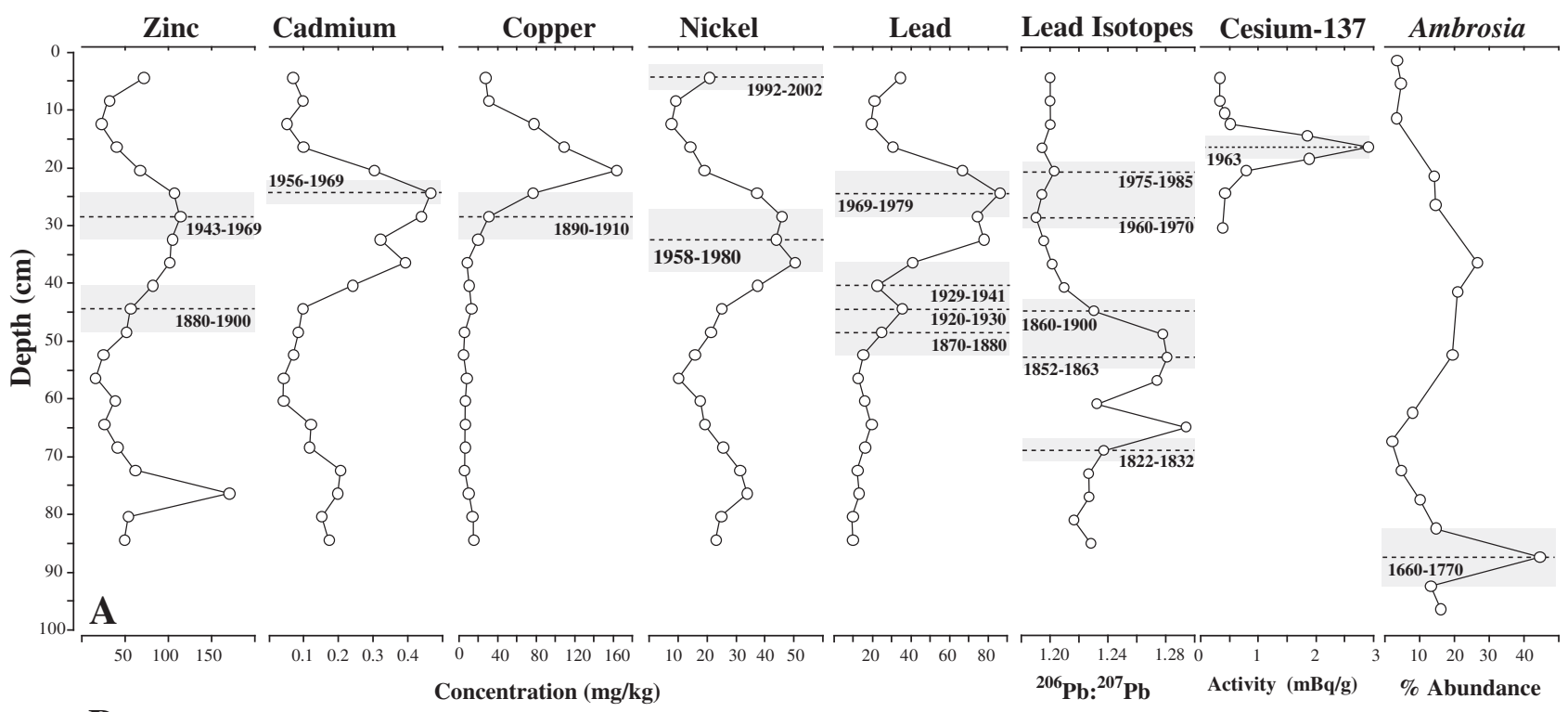

B
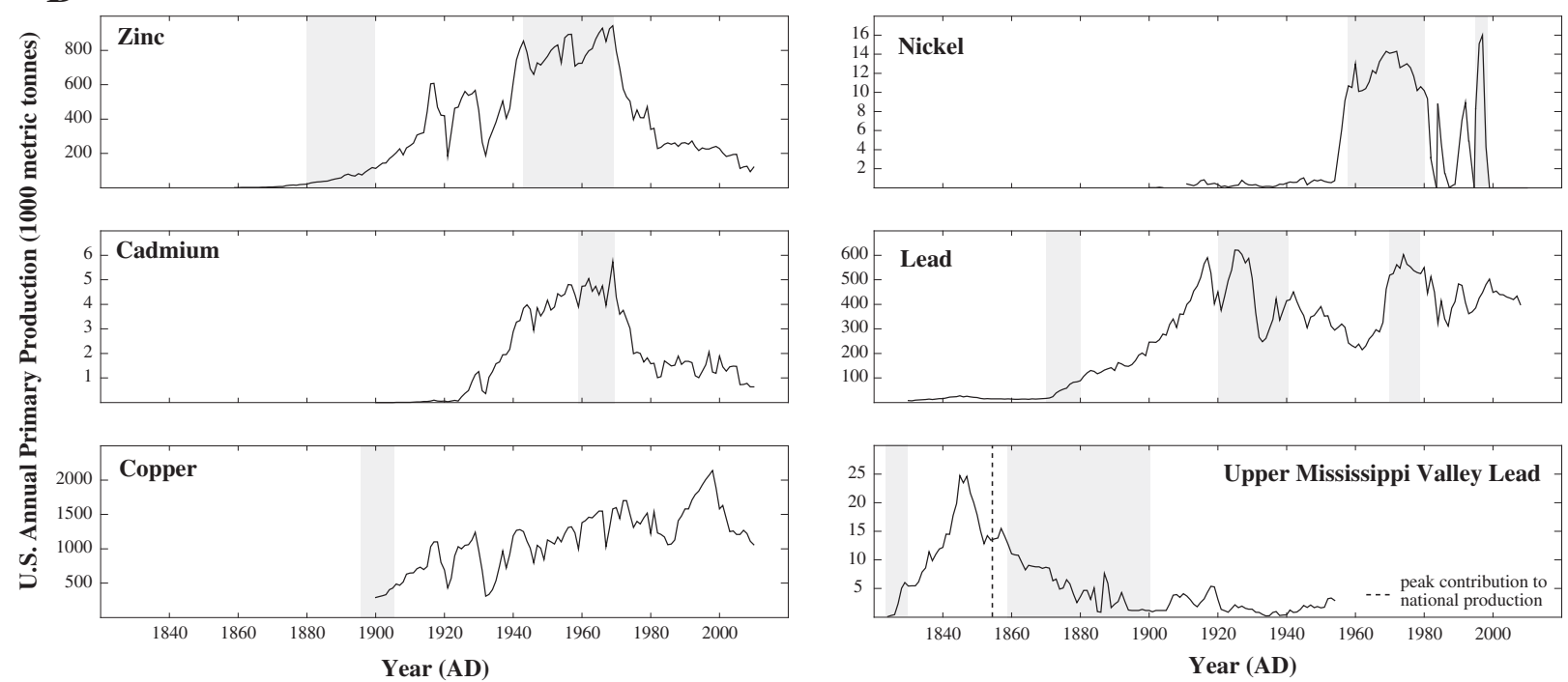

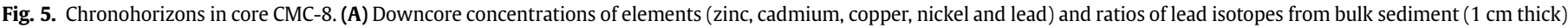

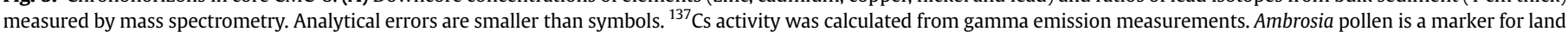
clearance during European settlement. Gray bands with ages represent core intervals recognized as corresponding to prominent features in U.S. national production records (B).

and White $(2006,2011)$ recognized an increase in the rate of sealevel rise at around $1930 \mathrm{AD}$, but concluded that the primary change from background to modern rates of rise likely occurred prior to $1870 \mathrm{AD}$. Therefore, the onset of modern rates of sea-level rise pre-dates all tide gauges in New Jersey and almost all globally. Based on the limited number of pre-1870 AD gauges, Jevrejeva et al. (2008) developed a global tide-gauge record since $1700 \mathrm{AD}$ and concluded that accelerated sea-level rise may have begun in the late 18th century. Sea-level reconstructions from salt-marsh sediment address the limited duration of instrumental data and estimate when modern rates of rise began (Barlow et al., 2013). In North Carolina, change point analysis identified the increase in rate as occurring between 1865 AD and 1892 AD (Kemp et al., 2011). In Connecticut, the change was identified in the second half of the 19th century from the difference between reconstructed background rates and modern rates of rise measured by tide gauges (Donnelly et al., 2004). From a salt-marsh reconstruction in Nova Scotia, the transition to modern rates of rise was subjectively identified between $1930 \mathrm{AD}$ and $1940 \mathrm{AD}$ from the intersection of two linear regressions without formal consideration of temporal and vertical uncertainties in the sea-level reconstruction (Gehrels et al., 2005; Gehrels and Woodworth, 2012). Using the same approach, sea-level reconstructions from the southern hemisphere (Tasmania and New Zealand) placed the inflection in the rate of sealevel rise between 1895 AD and 1925 AD (Gehrels et al., 2008; Gehrels and Woodworth, 2012; Gehrels et al., 2012). This difference in timings may reflect a real global pattern or be a consequence of the methods used to estimate timing and rates.

The reconstructed rate of sea-level rise in New Jersey since the inflection between $1865 \mathrm{AD}$ and $1892 \mathrm{AD}$ is $3.1 \mathrm{~mm} / \mathrm{yr}$ (95\% confidence interval of $2.8 \mathrm{~mm} / \mathrm{yr}$ to $3.5 \mathrm{~mm} / \mathrm{yr}$; Fig. 9a, Table 2) and is unprecedented for at least 2500 years. This rate exceeds the global average estimated for the 20th century of $1.7 \mathrm{~mm} / \mathrm{yr}$ (Church and White, 2006, 2011) as well as the U.S. Atlantic coast average of $1.8 \mathrm{~mm} / \mathrm{yr}$ (Engelhart et al., 2009). It also exceeds the reconstructed rate for this period from regions to the south (North Carolina, $2.1 \mathrm{~mm} / \mathrm{yr}$ ) and north of New Jersey (Nova Scotia, $1.4 \mathrm{~mm} / \mathrm{yr}$ ) on the Atlantic coast of North America. Processes causing exaggerated 


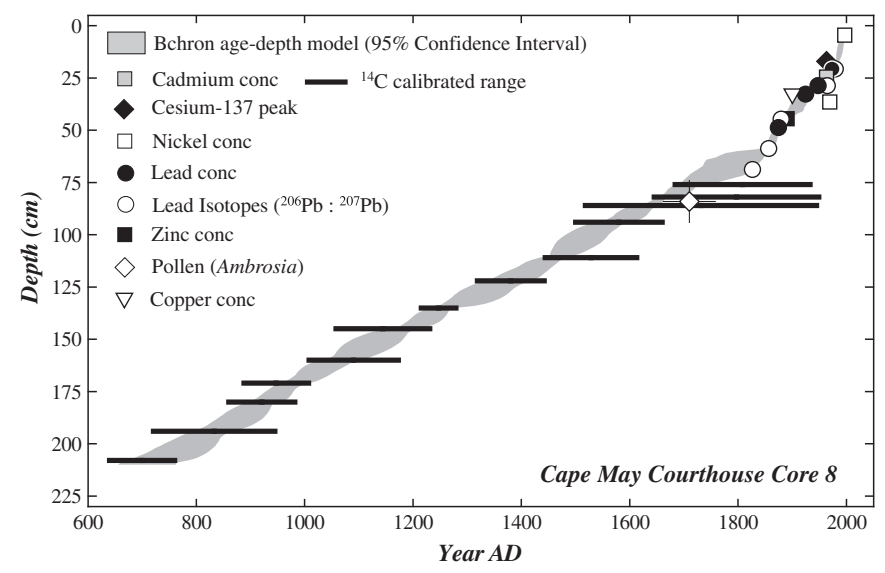

Fig. 6. Chronology developed for core CMC-8. Thirteen, identifiable plant macrofossils were radiocarbon dated and constrained the Bchron age model (shaded gray envelope). Solid horizontal bars represent the full range of calibrated ages rather than their probability distribution. Pollution chronohorizons were recognized by downcore changes in elemental concentration, lead isotopic ratios and ${ }^{137} \mathrm{Cs}$ activity that could be related to features in historic production statistics. An increase in Ambrosia pollen was interpreted as being caused by land clearance during European settlement in the study region.
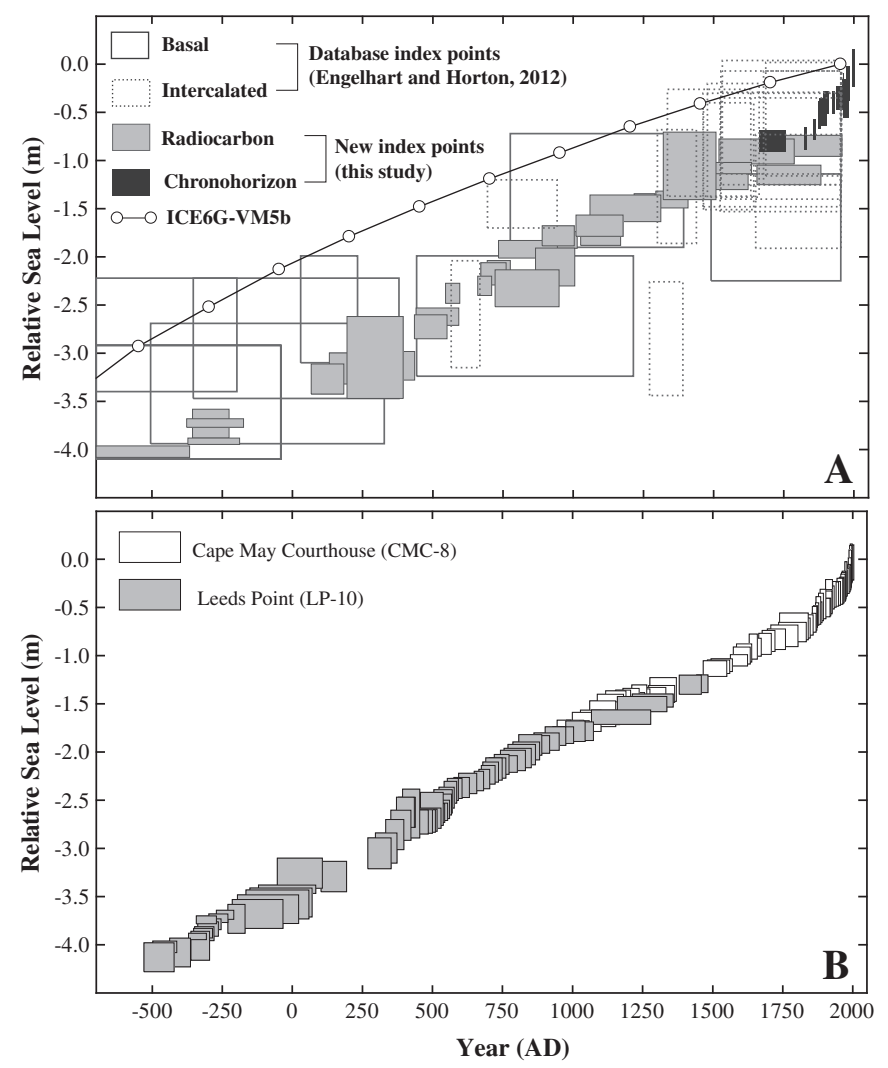

Fig. 7. Relative sea-level reconstruction from southern New Jersey. (A) New index points from Leeds Point and Cape May Courthouse with vertical and age error reported following the same conventions as those from a database of radiocarbon dated index points in New Jersey. Relative sea-level predictions for Cape May Couthouse from the ICE6G-VM5b model are shown at 250 year time steps as open circles (B) Relative sea level reconstructed from Leeds Point core 10 and Cape May Courthouse core 8 using foraminifera with stable carbon isotopes as sea-level indicators and a composite chronology developed with Bchron age depth models to estimate sample age and uncertainty. Data points are represented by boxes that incorporate the vertical and temporal uncertainty from these two sources, but do not show associated probability distributions within each box. rates of land subsidence such as ground water withdrawal are often invoked for explaining the high rate of sea-level rise at the New Jersey coast (Davis, 1987; Sun et al., 1999). Local and sub-regional scale factors such as these are not captured by the database of sea-level index points used to estimate land-level change, particularly if the process(es) began in the historical period (e.g. groundwater pumping). However, the high degree of coherence among New Jersey tide gauges (Fig. 8a) suggests that a regional rather than local process is the driving mechanism. Regional land-level changes in addition to GIA (e.g. long term subsidence of the coastal plain) cannot be invoked as the cause of the high rate of sea-level rise since these are inherently included in the regional database of sealevel index points. Similarly a methodological effect (e.g. change in dating methods) cannot be invoked since the reconstructions are in agreement with regional tide-gauge data (Fig. 8) and the same approach used elsewhere (e.g. Nova Scotia, North Carolina) did not generate such high rates of rise. Therefore, the high rate of regional sea-level rise in New Jersey since $\sim 1850$ AD is attributed to oceanographic, ocean mass, or ocean volume effects. New Jersey is located in the region between Cape Hatteras and Cape Cod where tide gauges recorded rates of rise considerably greater than the global mean during the 20th century (Boon, 2012; Sallenger et al., 2012). In an alternative analysis of the same tide-gauge data, Kopp (2013) concluded that it was too early to attribute the spatial pattern to ocean dynamic variability or a long-term trend. Model results predict that changes in ocean circulation in the 21 st century would result in excess sea-level rise (up to $\sim 0.3 \mathrm{~m}$ ) along the northeastern coast of the United States (Yin et al., 2009). The high rate of sea-level rise reconstructed in New Jersey is in agreement with instrumental measurements and indicates that regional processes began to cause this spatial pattern of excess sea-level rise around $1850 \mathrm{AD}$.

Prior to the onset of increased rates of sea-level rise around $1850 \mathrm{AD}$, New Jersey experienced three additional periods of persistent sea-level trends (Fig. 9a). Phases of late Holocene sealevel rise representing departures from a linear trend have also been reconstructed in Connecticut (Thomas and Varekamp, 1991; van de Plassche et al, 1998; van de Plassche, 2000), but in some cases were reinterpreted as sedimentary features caused by erosion of salt marshes during hurricanes or large storms followed by rapid infilling of accommodation space (van de Plassche et al., 2006). Salt-marsh reconstructions from Massachusetts (Kemp et al., 2011), Maine (Gehrels, 2000), and the Gulf of Mexico (González and Törnqvist, 2009) show evidence of late Holocene sea-level changes, but lack the resolution necessary to definitively identify these features within the limitations of age and sea-level uncertainties. The late Holocene reconstruction from North Carolina included four phases of sea-level change after adjustment for landlevel changes that could not be accommodated by a linear rate of change (Kemp et al., 2011). To ensure compatibility with the New Jersey reconstruction, the same error-in-variables change point model was applied to the North Carolina dataset. A model with three change points best described the reconstruction as evidenced by the lowest DIC, resulting in four persistent sea-level trends that are slightly different to those reported in Kemp et al. (2011). In North Carolina, sea level was stable from at least 100 BC to 968 AD. It then increased for $\sim 400$ years at a rate of $0.5 \mathrm{~mm} / \mathrm{yr}$, followed by a further period of stable, or slightly falling, sea level until the late 19th century. After $1877 \mathrm{AD}$, sea level rose at an average rate of $2.0 \mathrm{~mm} / \mathrm{yr}$ (Fig. 9b). These changes were attributed to climate variability, with sea-level rise being caused by Medieval warmth, stable or slightly falling sea level as a consequence of the cooler Little Ice Age, and the sharp rise since the end of the 19th century driven by contemporary warming (Kemp et al., 2011). With the exception of the historic onset of more rapid sea-level rise (1862- 

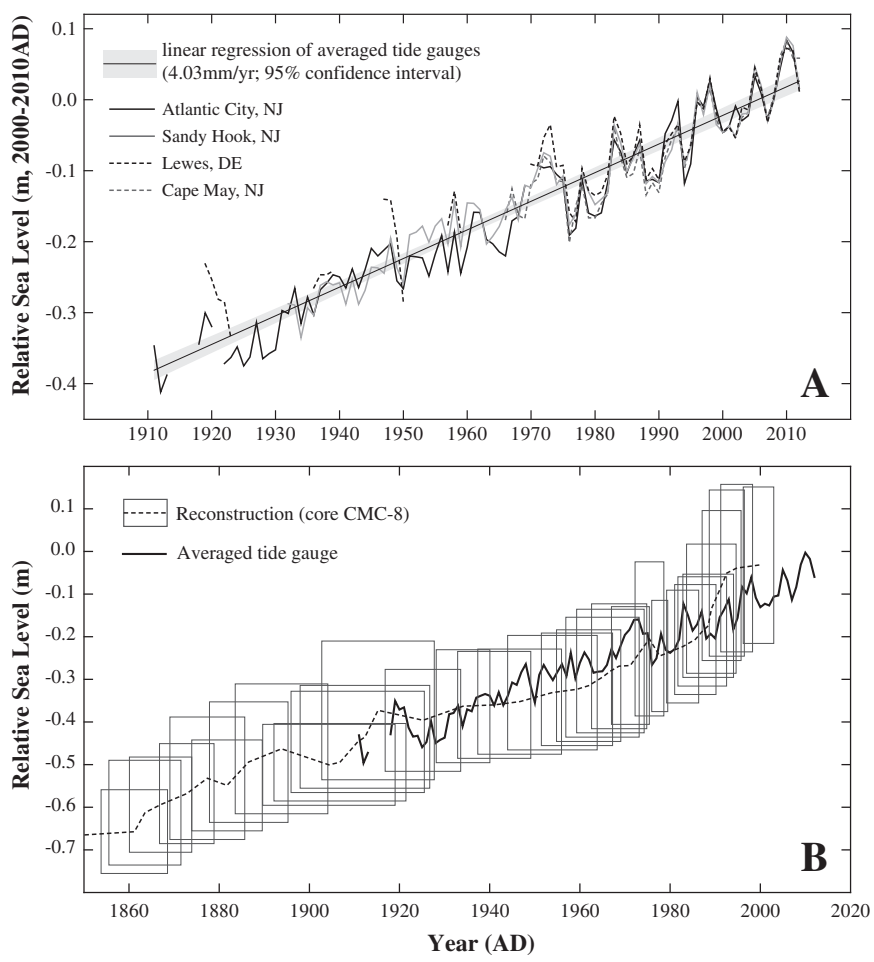

Fig. 8. (A) Tide-gauge records of relative sea level from sites in New Jersey and Delaware. Annual data computed from monthly means and plotted against the average for 2000-2010 AD for each gauge. A single record was compiled by averaging annual data from the four gauges. A linear regression of the averaged record shows that relative sea level rose at average rate of $4.03 \mathrm{~mm} / \mathrm{yr}$ between $1911 \mathrm{AD}$ and $2012 \mathrm{AD}$. (B) Comparison of the relative sea level reconstruction from Cape May Courthouse (dashed line) and a tide-gauge record produced by averaging annual data from Atlantic City, Sandy Hook, Cape May and Lewes (solid line). Tide-gauge data is relative to 2010 AD (year of core collection). Age and vertical uncertainties from the sea-level reconstruction are represented by boxes.

$1873 \mathrm{AD}$ is the period of mutual overlap), these phases are asynchronous with changes in New Jersey predating those in North Carolina.

Gehrels et al. (2005) recognized that calibrating radiocarbon ages from salt marshes can generate apparent sea-level changes that are artifacts of calibration. Using simulated radiocarbon dates spaced at regular temporal intervals, they generated stacked calibrated ages (more rapid "sea-level rise") at times when the calibration curve is relatively flat (plateaus) and multiple calibrated ranges are generated for a single date. Of interest to understanding the pattern of sea-level rise reconstructed in New Jersey are examples of these periods at around $800 \mathrm{AD}$ and $1600 \mathrm{AD}$. The asynchroneity and timing of sea-level rise in New Jersey (250 AD750 AD) and North Carolina (950 AD-1375 AD) indicates that these reconstructed trends are not artifacts of radiocarbon calibration. Since the two, independent, sea-level reconstructions span a similar period of time, with a similar concentration of radiocarbon dates, they would be expected to experience simultaneous changes in sea level if they were an artifact of calibration. Therefore, radiocarbon calibration is unlikely to be the cause of the reconstructed sea-level rise and a physical explanation must be sought. Alternatively, the differences between the North Carolina and New Jersey sea-level curves could potentially be explained by relaxing the assumption of constant, linear rates of vertical land-level change to allow a more complex spatio-temporal contribution to RSL from crustal motion. However, Earth-Ice models suggest that a linear rate of GIA is appropriate for the timescale under
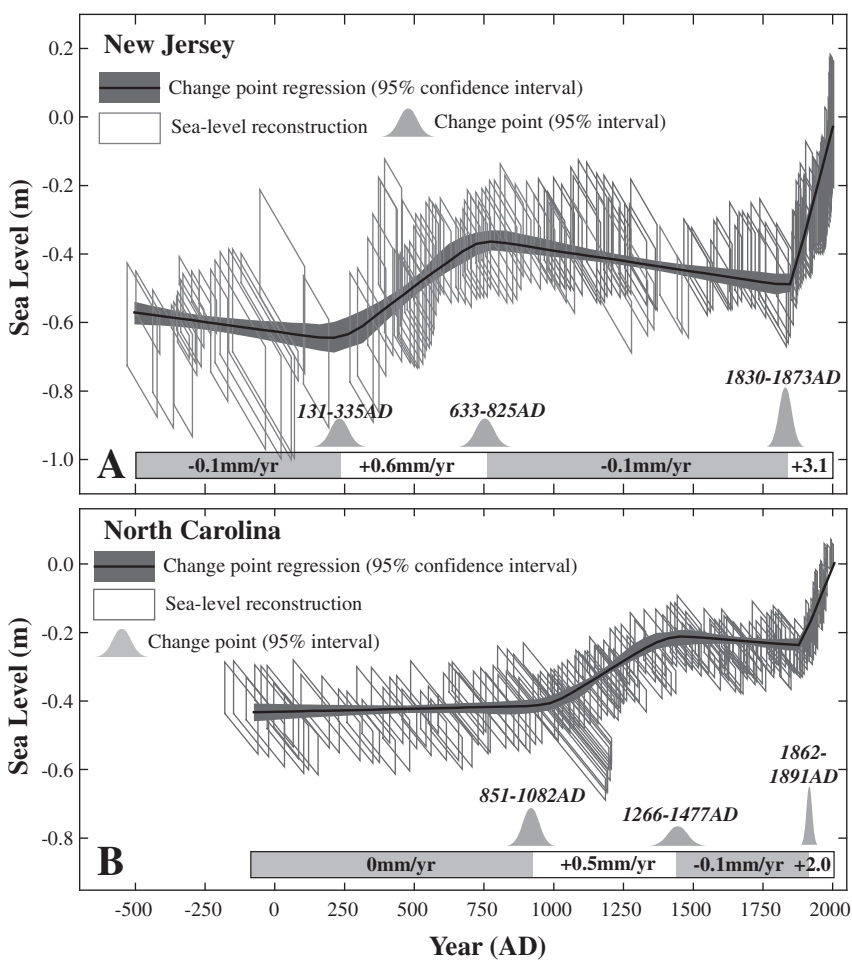

Fig. 9. New Jersey (A) and North Carolina (B) sea-level reconstructions with the estimated contribution of land-level change removed $(1.4 \mathrm{~mm} / \mathrm{yr}$ for New Jersey and $0.9 \mathrm{~mm} / \mathrm{yr}$ or $1.0 \mathrm{~mm} / \mathrm{yr}$ for North Carolina). Data points previously represented by rectangles have been distorted into parallelograms by subtraction of a rate that has a larger effect on the older edge of each box than it does on the younger edge. Average rates of sea-level change for four persistent phases are listed and the $95 \%$ confidence interval for the timing of rate changes are represented by probability distributions. The shaded bands are the best-fit change point regressions. The same change point model was applied to both records, causing marginally different results for North Carolina than those originally reported by (Kemp et al., 2011).

consideration and this assertion is supported by compilations of RSL contributions from the U.S. Atlantic coast (e.g. Engelhart et al., 2011a).

Although the first period of sea-level rise in New Jersey and North Carolina was asynchronous in timing, the rates of change (following correction of the land-level contribution) are similar. In both regions the rate of rise was $0.5 \mathrm{~mm} / \mathrm{yr}$ to $0.6 \mathrm{~mm} / \mathrm{yr}$, preceded by an interval of stable or slightly falling sea level $(0.0$ to $-0.1 \mathrm{~mm} /$ yr) and followed by a second period of stable sea level (Fig. 9). This agreement could indicate a common driving mechanism with a spatial lag time. The rise in North Carolina was attributed to a warmer global climate during the Medieval Climate Anomaly (Kemp et al., 2011). The reconstruction from New Jersey suggests a complex response of sea level to paleo-climate change that results in spatial variability. On decadal timescales, instrumental measurements of historic sea level indicate that steric expansion (e.g. Cazenave and Llovel, 2010) and ocean circulation (e.g. Bingham and Hughes, 2009; Kienert and Rahmstorf, 2012; Ezer et al., 2013) cause spatial variability in sea level along the U.S. Atlantic coast. It is currently unclear if these processes can be invoked as a plausible mechanism for explaining spatial variability on centennial timescales. However, the New Jersey and North Carolina reconstructions are currently the only two studies to cover the entire late Holocene with the resolution needed to identify this level of variability and test hypotheses about mechanisms for pre instrumental sea-level changes. Reconstructions from other locations that encompass this interval of sea-level variability rather than focusing exclusively 
Table 2

Change point analysis.

\begin{tabular}{|c|c|c|c|}
\hline No. of change points & Converged? & Deviance information criterion (DIC) & Timing of changes (AD) \\
\hline 0 & Yes & -1843.9 & \\
\hline 1 & Yes & -1859.5 & 1922 \\
\hline 2 & Yes & -1886.3 & 897 and 1855 \\
\hline 3 & Yes & -1938.7 & 246,733 , and 1850 \\
\hline 4 & No & No convergence & \\
\hline \multicolumn{4}{|l|}{3 Change Point Model } \\
\hline Interval & Rate (mm/yr; 95\% confidence) & Timing of change (AD; 95\% confidence) & \\
\hline $\mathrm{i}$ & -0.22 to -0.01 & & \\
\hline ii & 0.44 to 0.90 & $131-335$ & \\
\hline iii & -0.18 to -0.07 & $633-825$ & \\
\hline iv & 2.81 to 3.47 & $1830-1873$ & \\
\hline
\end{tabular}

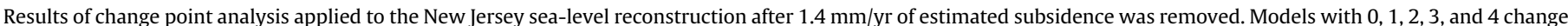

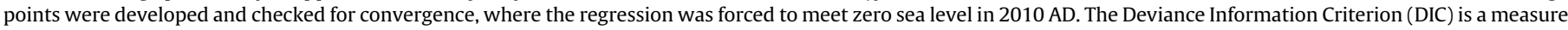

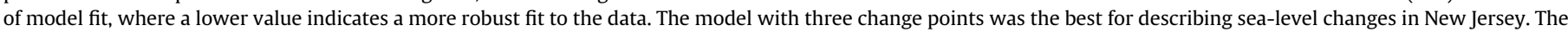
95\% confidence interval for the four periods of persistent sea-level trends and timing of three change points is provided for the selected model.

on the transition to modern rates of rise are needed to elucidate a coherent evolution of late Holocene sea-level change. Understanding the origin and causes of these phases of late Holocene sealevel change will help to predict the future response of sea level to projected changes in global climate.

\section{Conclusions}

Relative sea level was reconstructed at two sites in New Jersey from sequences of salt-marsh sediment. A multi-proxy approach combining a transfer function trained on the modern distribution of foraminifera and bulk sediment $\delta^{13} \mathrm{C}$ values as sea-level indicators estimated the elevation at which samples formed in one of three ways. (i) For samples with a $\delta^{13} \mathrm{C}$ value more depleted than $-22 \%$, the transfer function estimate was trimmed to retain only the range above MHHW and reflect the dominance of $\mathrm{C}_{3}$ plants; (ii) For samples with a $\delta^{13} \mathrm{C}$ value less depleted than $-18.9 \%$, the transfer function estimate was trimmed to retain only the range below MHHW and reflect the dominance of $\mathrm{C}_{4}$ plants; and (iii) For samples with intermediate $\delta^{13} \mathrm{C}$ values $(-22.0 \%$ to $-18.9 \%$ ), and/or transfer function estimates that did not encompass MHHW, the full range of the original transfer function was retained. In comparison to transfer function estimates of paleomarsh elevation, this multi-proxy approach reduced vertical uncertainty in reconstructing sea level by about one third. Sample ages were estimated using an age-depth model developed from a composite chronology of radiocarbon dates and chrono-horizons recognized by changes in elemental concentration, ${ }^{137} \mathrm{Cs}$ activity, ratios of lead isotopes and pollen abundance that were related to historical trends. Age estimates from ${ }^{210} \mathrm{~Pb}$ were excluded because they are not independent of one another and their inclusion would cause bias in the resulting age-depth model. The RSL reconstructions span the last 2500 years with an average vertical uncertainty of $\pm 0.12 \mathrm{~m}$ and average age uncertainty of \pm 32 years.

To test if sea level was stable during the late Holocene and to identify positive and negative departures from background rates of change, an estimated rate of land subsidence $(1.4 \mathrm{~mm} / \mathrm{yr})$ was removed. Change point analysis identified four periods of persistent (multi-centennial) sea-level trends in the resulting record. These deviations confirm that late Holocene sea level in New Jersey was not stable. From at least $500 \mathrm{BC}$ to $250 \mathrm{AD}$ sea level fell at $0.11 \mathrm{~mm} / \mathrm{yr}$. Sea-level rose at $0.62 \mathrm{~mm} / \mathrm{yr}$ from $250 \mathrm{AD}$ to $733 \mathrm{AD}$. Between $733 \mathrm{AD}$ and $1850 \mathrm{AD}$ sea level fell at $0.12 \mathrm{~mm} / \mathrm{yr}$. Since $1850 \mathrm{AD}$ the reconstructed rate of sea-level rise was $3.1 \mathrm{~mm} / \mathrm{yr}$, which is greater than any other persistent trend in at least the preceding 2500 years. The modern rate of rise is in agreement with regional tide-gauge records and exceeds the global average estimate for the 20th century. The asynchroneity of Medieval sea level rise between New Jersey and North Carolina suggests that the reconstructed sea-level variability is not an artifact of radiocarbon calibration and therefore requires a physical explanation.

\section{Acknowledgments}

This work was supported by National Oceanic and Atmospheric Administration award NA11OAR4310101 and NSF grants EAR1052848 and EAR-0951686. Kemp thanks a graduate student internship at NOSAMS that provided radiocarbon dating under the supervision of Dr. Mark Roberts. Vane publishes with permission of the director of the British Geological Survey who partially supported this work through the BGS Climate and Landscape research program. We thank the Edwin Forsythe National Wildlife Refuge (U.S. Fish and Wildlife Service) for granting access and student volunteers from the Earthwatch Student Challenge Award Program for their enthusiastic help for in fieldwork. We thank Daria Nikitina, Nicole Khan, Jessica Pilarczyk, and Andrea Hawkes for their assistance in the field and in the lab. W.R. Peltier and R. Drummond kindly provided the Earth-Ice model predictions for the study sites. This is a contribution to PALSEA and IGCP Project 588 "Preparing for Coastal Change". The manuscript benefited from the thoughtful and productive comments of Tom Cronin (USGS) and two anonymous reviewers.

\section{Appendix A. Supplementary data}

Supplementary data related to this article can be found at http:// dx.doi.org/10.1016/j.quascirev.2013.09.024.

\section{References}

Ahmed, M., Anchukaitis, K.J., Asrat, A., Borgaonkar, H.P., Braida, M., Buckley, B.M., Buntgen, U., Chase, B.M., Christie, D.A., Cook, E.R., Curran, M.A.J., Diaz, H.F. Esper, J., Fan, Z.-X., Gaire, N.P., Ge, Q., Gergis, J., Gonzalez-Rouco, J.F., Goosse, H. Grab, S.W., Graham, N., Graham, R., Grosjean, M., Hanhijarvi, S.T., Kaufman, D.S. Kiefer, T., Kimura, K., Korhola, A.A., Krusic, P.J., Lara, A., Lezine, A.-M. Ljungqvist, F.C., Lorrey, A.M., Luterbacher, J., Masson-Delmotte, V., McCarroll, D. McConnell, J.R., McKay, N.P., Morales, M.S., Moy, A.D., Mulvaney, R., Mundo, I.A. Nakatsuka, T., Nash, D.J., Neukom, R., Nicholson, S.E., Oerter, H., Palmer, J.G., Phipps, S.J., Prieto, M.R., Rivera, A., Sano, M., Severi, M., Shanahan, T.M., Shao, X. Shi, F., Sigl, M., Smerdon, J.E., Solomina, O.N., Steig, E.J., Stenni, B., Thamban, M., Trouet, V., Turney, C.S.M., Umer, M., van Ommen, T., Verschuren, D., Viau, A.E. Villalba, R., Vinther, B.M., von Gunten, L., Wagner, S., Wahl, E.R., Wanner, H. Werner, J.P., White, J.W.C., Yasue, K., Zorita, E., 2013. Continental-scale temperature variability during the past two millennia. Nat. Geosci.. Advance Online Publication. 
Ault, W.U., Senechal, R.G., Erlebach, W.E., 1970. Isotopic composition as a natural tracer of lead in the environment. Environ. Sci. Technol. 4, 305-313.

Barlow, N.L.M., Shennan, I., Long, A.J., Gehrels, W.R., Saher, M.H., Woodroffe, S.A., Hillier, C., 2013. Salt marshes as late Holocene tide gauges. Global Planet. Change 106, 90-110.

Benner, R., Fogel, M.L., Sprague, E.K., 1991. Diagenesis of belowground biomass of Spartina alterniflora in salt-marsh sediments. Limnol. Oceanogr. 36, 1358-1374.

Benner, R., Fogel, M.L., Sprague, E.K., Hodson, R.E., 1987. Depletion of ${ }^{13} \mathrm{C}$ in lignin and its implications for stable isotope studies. Nature 329, 708-710.

Bindoff, N.L., Willebrand, J., Artale, V., Cazenave., A., Gregory, J., Gulev, S., Hanawa, K., Quéré, C.L., Levitus, S., Nojiri, Y., Shum, C.K., Talley, L.D. Unnikrishnan, A., 2007. Observations: oceanic climate change and sea level. In: Solomon, S., Qin, D., Mannin, M., Chen, Z., Marquis, M., Avery, K.B., Tignor, M. Miller, H.L. (Eds.), Climate Change 2007: the Physical Science Basis, Contribution of Working Group I to the Fourth Assessment Report of the Intergovernmental Panel on Climate Change Cambridge University Press, Cambridge.

Bingham, R.J., Hughes, C.W., 2009. Signature of the Atlantic meridional overturning circulation in sea level along the east coast of North America. Geophys. Res. Lett. 36, L02603.

Birks, H.J.B., 1998. Numerical tools in paleolimnology - progress, potentialities and problems. J. Paleolimnol. 20, 307-332.

Bittermann, K., Rahmstorf, S., Perrette, M., Vermeer, M., 2013. Predictability of twentieth century sea-level rise from past data. Environ. Res. Lett. 8, 014013.

Bleiwas, D.I., DiFrancesco, C., 2010. Historical Zinc Smelting in New Jersey, Pennsylvania, Virginia, West Virginia, and Washington, D.C., with Estimates of Atmospheric Zinc Emissions and Other Materials. Open File Report 2010-1131. United States Geological Survey, p. 189.

Bollhöfer, A., Rosman, K.J.R., 2001. Isotopic source signatures for atmospheric lead: the Northern Hemisphere. Geochim. Cosmochim. Acta 65, 1727-1740.

Boon, J.D., 2012. Evidence of sea level acceleration at U.S. and Canadian tide stations, Atlantic coast, North America. J. Coast Res. 28, 1437-1445.

Brain, M.J., Long, A.J., Woodroffe, S.A., Petley, D.N., Milledge, D.G., Parnell, A.C., 2012 Modelling the effects of sediment compaction on salt marsh reconstructions of recent sea-level rise. Earth Planet. Sci. Lett. 345-348, 180-193.

Byrne, R., Ingram, B.L., Starratt, S., Malamud-Roam, F., Collins, J.N., Conrad, M.E. 2001. Carbon-isotope, diatom, and pollen evidence for Late Holocene salinity change in a brackish marsh in the San Francisco Estuary. Quater. Res. $55,66-76$.

Cazenave, A., Llovel, W., 2010. Contemporary sea level rise. Annu. Rev. Mar. Sci. 2. $145-173$.

Chmura, G.L., Aharon, P., 1995. Stable carbon isotope signatures of sedimentary carbon in coastal wetlands as indicators of salinity regime. J. Coast. Res. 11, 124-135.

Church, J., White, N., Aarup, T., Wilson, W., Woodworth, P., Domingues, C., Hunter, J. Lambeck, K., 2008. Understanding global sea levels: past, present and future. Sustain. Sci. 3, 9-22.

Church, J.A., White, N.J., 2006. A 20th century acceleration in global sea-level rise Geophys. Res. Lett. 33, L01602.

Church, J.A., White, N.J., 2011. Sea-level rise from the late 19th to the early 21st century. Surv. Geophys. 32, 585-602.

Cronin, T.M., 2012. Rapid sea-level rise. Quat. Sci. Rev. 56, 11-30.

Daddario, J.J., 1961. A lagoon deposit profile near Atlantic City, New Jersey. Bull. N. J. Acad. Sci. 6, 7-14.

Davis, G.H., 1987. Land subsidence and sea level rise on the Atlantic Coastal Plain of the United States. Environ. Geol. Water Sci. 10, 67-80.

Donnelly, J.P., Cleary, P., Newby, P., Ettinger, R., 2004. Coupling instrumental and geological records of sea-level change: evidence from southern New England of an increase in the rate of sea-level rise in the late 19th century. Geophys. Res. Lett. 31, L05203.

Ember, L.M., Williams, D.F., Morris, J.T., 1987. Processes that influence carbon isotope variations in salt marsh sediments. Mar. Ecol. Prog. Ser. 36, 33-42.

Engelhart, S.E., Horton, B.P., 2012. Holocene sea level database for the Atlantic coast of the United States. Quat. Sci. Rev. 54, 12-25.

Engelhart, S.E., Horton, B.P., Douglas, B.C., Peltier, W.R., Tornqvist, T.E., 2009. Spatia variability of late Holocene and 20th century sea-level rise along the Atlantic coast of the United States. Geology 37, 1115-1118.

Engelhart, S.E., Horton, B.P., Kemp, A.C., 2011a. Holocene sea level changes along the United States' Atlantic Coast. Oceanography 24, 70-79.

Engelhart, S.E., Peltier, W.R., Horton, B.P., 2011b. Holocene relative sea-level changes and glacial isostatic adjustment of the U.S. Atlantic coast. Geology 39, 751-754.

Ezer, T., Atkinson, L.P., Corlett, W.B., Blanco, J.L., 2013. Gulf Stream's induced se level rise and variability along the U.S. mid-Atlantic coast. J. Geophys. Res. Oceans 118, 685-697.

Ferland, M.A., 1990. Holocene Depositional History of the Southern New Jersey Barrier and Back Barrier Regions. US Army Corps of Engineers, p. 75.

Fogel, M.L., Kent Sprague, E., Gize, A.P., Frey, R.W., 1989. Diagenesis of organic matter in Georgia salt marshes. Estuar. Coast. Shelf Sci. 28, 211-230.

Gehrels, W.R., 2000. Using foraminiferal transfer functions to produce highresolution sea-level records from salt-marsh deposits, Maine, USA. Holocene 10, 367-376.

Gehrels, W.R., Callard, S.L., Moss, P.T., Marshall, W.A., Blaauw, M., Hunter, J. Milton, J.A., Garnett, M.H., 2012. Nineteenth and twentieth century sea-leve changes in Tasmania and New Zealand. Earth Planet. Sci. Lett. 315-316, 94102

Gehrels, W.R., Hayward, B., Newnham, R.M., Southall, K.E., 2008. A 20th century acceleration of sea-level rise in New Zealand. Geophys. Res. Lett. 35, L02717.
Gehrels, W.R., Kirby, J.R., Prokoph, A., Newnham, R.M., Achterberg, E.P., Evans, H., Black, S., Scott, D.B., 2005. Onset of recent rapid sea-level rise in the western Atlantic Ocean. Quat. Sci. Rev. 24, 2083-2100.

Gehrels, W.R., Woodworth, P.L., 2012. When did modern rates of sea-level rise start? Global Planet. Change 100, 263-277.

Gobeil, C., Tessier, A., Couture, R.-M., 2013. Upper Mississippi Pb as a mid-1800s chronostratigraphic marker in sediments from seasonally anoxic lakes in Eastern Canada. Geochim. Cosmochim. Acta 113, 125-135.

Goñi, M., Thomas, K., 2000. Sources and transformations of organic matter in surface soils and sediments from a tidal estuary (North Inlet, South Carolina, USA). Estuar. Coasts 23, 548-564.

González, J.L., Törnqvist, T.E., 2009. A new Late Holocene sea-level record from the Mississippi Delta: evidence for a climate/sea level connection? Quat. Sci. Rev. 28, 1737-1749.

Graney, J.R., Halliday, A.N., Keeler, G.J., Nriagu, J.O., Robbins, J.A., Norton, S.A., 1995. Isotopic record of lead pollution in lake sediments from the northeastern United States. Geochim. Cosmochim. Acta 59, 1715-1728.

Haslett, J., Parnell, A., 2008. A simple monotone process with application to radiocarbon-dated depth chronologies. J. R. Stat. Soc. Ser. C (Appl. Stat.) 57, 399-418.

Horton, B., Engelhart, S.E., Hill, D.F., Kemp, A.C., Nikitina, D.L., Miller, K.G., Peltier, R.W., 2013. Influence of tidal-range change and sediment compaction on Holocene relative sea-level change in New Jersey, USA. J. Quat. Sci. 28, 403-411.

Horton, B.P., Edwards, R.J., 2006. Quantifying Holocene Sea-level Change Using Intertidal Foraminifera: Lessons from the British Isles. In: Cushman Foundation for Foraminiferal Research, Special Publication 40, p. 97.

Jevrejeva, S., Moore, J.C., Grinsted, A., Woodworth, P.L., 2008. Recent global sea level acceleration started over 200 years ago? Geophys. Res. Lett. 35, L08715.

Johnson, B.J., Moore, K.A., Lehmann, C., Bohlen, C., Brown, T.A., 2007. Middle to late Holocene fluctuations of $C_{3}$ and $C_{4}$ vegetation in a Northern New England Salt Marsh, Sprague Marsh, Phippsburg Maine. Org. Geochem. 38, 394-403.

Kemp, A.C., Horton, B., Donnelly, J.P., Mann, M.E., Vermeer, M., Rahmstorf, S., 2011. Climate related sea-level variations over the past two millennia. Proc. Natl. Acad. Sci. 108, 11017-11022.

Kemp, A.C., Horton, B.P., Vann, D.R., Engelhart, S.E., Vane, C.H., Nikitina, D., Anisfeld, S.C., 2012a. Quantitative vertical zonation of salt-marsh foraminifera for reconstructing former sea level; an example from New Jersey, USA. Quat. Sci. Rev. 54, 26-39.

Kemp, A.C., Sommerfield, C.K., Vane, C.H., Horton, B.P., Chenery, S.R., Anisfeld, S.C., Nikitina, D., 2012b. Use of lead isotopes for developing chronologies in recent salt-marsh sediments. Quat. Geochronol. 12, 40-49.

Kemp, A.C., Telford, R.J., Horton, B.P., Anisfeld, S.C., Sommerfield, C.K., 2013. Reconstructing Holocene sea-level using salt-marsh foraminifera and transfer functions: lessons from New Jersey, USA. J. Quat. Sci. 28, 617-629.

Kemp, A.C., Vane, C.H., Horton, B.P., Engelhart, S.E., Nikitina, D., 2012c. Application of stable carbon isotopes for reconstructing salt-marsh floral zones and relative sea level, New Jersey, USA. J. Quat. Sci. 27, 404-414.

Kienert, H., Rahmstorf, S., 2012. On the relation between Meridional Overturning Circulation and sea-level gradients in the Atlantic. Earth Syst. Dyn. 3, 109-120.

Kopp, R.E., 2013. Does the mid-Atlantic United States sea level acceleration hot spot reflect ocean dynamic variability? Geophys. Res. Lett. 40, 3981-3985.

Lamb, A.L., Wilson, G.P., Leng, M.J., 2006. A review of coastal palaeoclimate and relative sea-level reconstructions using $\delta^{13} \mathrm{C}$ and $\mathrm{C} / \mathrm{N}$ ratios in organic material. Earth-sci. Rev. 75, 29-57.

Lima, A.L., Bergquist, B.A., Boyle, E.A., Reuer, M.K., Dudas, F.O., Reddy, C.M., Eglinton, T.I., 2005. High-resolution historical records from Pettaquamscutt River basin sediments: 2 . Pb isotopes reveal a potential new stratigraphic marker: Geochim. Cosmochim. Acta 69, 1813-1824.

Malamud-Roam, F., Ingram, B.L., 2004. Late Holocene $\mathrm{d}^{13} \mathrm{C}$ and pollen records of paleosalinity from tidal marshes in the San Francisco Bay estuary, California. Quat. Res. 62, 134-145.

Mann, M.E. Zhang, Z., Hughes, M.K., Bradley, R.S., Miller, S.K., Rutherford, S., Ni, F., 2008. Proxy-based reconstructions of hemispheric and global surface temperature variations over the past two millennia. Proc. Natl. Acad. Sci. U. S. A. 105, $13252-13257$

Marshall, W.A., Gehrels, W.R., Garnett, M.H., Freeman, S.P.H.T., Maden, C., Xu, S., 2007. The use of 'bomb spike' calibration and high-precision AMS C-14 analyses to date salt-marsh sediments deposited during the past three centuries. Quat. Res. 68, 325-337.

Meyerson, A.L., 1972. Pollen and paleosalinity analyses from a Holocene tidal marsh sequence, Cape May County, New Jersey. Mar. Geol. 12, 335-357.

Middleburg, J.J., Nieuwenhuize, J., Lubberts, R.K., van de Plassche, O., 1997. Organic carbon isotope systematics of coastal marshes. Estuar. Coast. Shelf Sci. $45,681-687$.

Miller, K.G., Sugarman, P.J., Browning, J.V., Horton, B.P., Stanley, A., Kahn, A., Uptegrove, J., Aucott, M., 2009. Sea-level rise in New Jersey over the past 5000 years: implications to anthropogenic changes. Global Planet. Change 66, 10-18.

Moberg, A., Sonechkin, D.M., Holmgren, K., Datsenko, N.M., Karlen, W., 2005. Highly variable Northern Hemisphere temperatures reconstructed from low- and high-resolution proxy data. Nature 433, 613-617.

Morris, J.T., Sundareshwar, P.V., Nietch, C.T., Kjerfve, B., Cahoon, D.R., 2002. Response of coastal wetlands to rising sea level. Ecology 83, 2869-2877.

Parnell, A.C., Haslett, J., Allen, J.R.M., Buck, C.E., Huntley, B., 2008. A flexible approach to assessing synchroneity of past events using Bayesian reconstructions of sedimentation history. Quater. Sci. Rev. 27, 1872-1885. 
Psuty, N.P., 1986. Holocene sea level in New Jersey. Phys. Geogr. 7, 156-167.

Rahmstorf, S., 2007. A semi-empirical approach to projecting future sea-level rise. Science 315, 368-370.

Reimer, P.J., Baillie, M.G.L., Bard, E., Bayliss, A., Beck, J.W., Blackwell, P.G., Ramsey, C.B., Buck, C.E., Burr, G.S., Edwards, R.L., Friedrich, M., Grootes, P.M., Guilderson, T.P., Hajdas, I., Heaton, T.J., Hogg, A.G., Hughen, K.A., Kaiser, K.F. Kromer, B., McCormac, F.G., Manning, S.W., Reimer, R.W., Richards, D.A., Southon, J.R., Talamo, S., Turney, C.S.M., van der Plicht, J., Weyhenmeyer, C.E., 2011. IntCal09 and Marine09 radiocarbon age calibration curves, 050,000 years cal. BP. Radiocarbon 51, 1111-1150.

Sallenger, A.H., Doran, K.S., Howd, P.A., 2012. Hotspot of accelerated sea-level rise on the Atlantic coast of North America. Nat. Clim. Change 2, 884-888.

Scott, D.B., Medioli, F.S., 1978. Vertical zonations of marsh foraminifera as accurate indicators of former sea levels. Nature 272, 528-531.

Shennan, I., Milne, G., Bradley, S., 2012. Late Holocene vertical land motion and relative sea-level changes: lessons from the British Isles. J. Quat. Sci. 27, 64-70.

Simpson, G.L., 2007. Analogue methods in Palaeoecology: using the analogue package. J. Stat. Softw. 22, 1-29.

Simpson, G.L., Hall, R.I., 2012. Human impacts: applications of numerical methods to evaluate surface water acidification and eutrophication. In: Birks, H.J.B., Lotter, A.F., Juggins, S., Smol, J.P. (Eds.), Data Handling and Numerical Techniques. Springer, pp. 579-614.

Sivan, D., Lambeck, K., Toueg, R., Raban, A., Porath, Y., Shirman, B., 2004. Ancient coastal wells of Caesarea Maritima, Israel, an indicator for relative sea level changes during the last 2000 years. Earth Planet. Sci. Lett. 222, 315-330.

Spiegelhalter, D.J., Best, N.G., Carlin, B.P., Van Der Linde, A., 2002. Bayesian measures of model complexity and fit. J R. Stat. Soc. Ser. B (Stat. Methodol.) 64, 583-639.

Stuckey, I.H., Gould, L.L., 2000. Coastal Plants from Cape Cod to Cape Canaveral. University of North Carolina Press, Chapel Hill.

Sun, H., Grandstaff, D., Shagam, R., 1999. Land subsidence due to groundwater withdrawal: potential damage of subsidence and sea level rise in southern New Jersey, USA. Environ. Geol. 37, 290-296.

Tanner, B.R., Uhle, M.E., Mora, C.I., Kelley, J.T., Schuneman, P.J., Lane, C.S., Allen, E.S. 2010. Comparison of bulk and compound-specific $\delta^{13} \mathrm{C}$ analyses and determination of carbon sources to salt marsh sediments using n-alkane distributions (Maine, USA). Estuar. Coast. Shelf Sci. 86, 283-291.

Thomas, E., Varekamp, J. 1991. Paleo-environmental analysis of marsh sequences (Clinton, CT); evidence for punctuated sea-level rise during the latest Holocene. J. Coast. Res. 11, 125-158.

Thompson, L.G., Mosley-Thompson, E., Davis, M.E., Zagorodnov, V.S., Howat, I.M., Mikhalenko, V.N., Lin, P.N., 2013. Annually resolved ice core records of tropical climate variability over the past $\sim 1800$ years. Science 340 (6135), 945-950.
Tiner, R.W., 1985. Wetlands of New Jersey. In: Service, U.S.F.a.W (Ed.), Nationa Wetlands Inventory. U.S. Fish and Wildlife Service, Newton Corner, MA, p. 117. Traverse, A., 2007. Paleopalynology. Springer.

van de Plassche, O., 2000. North Atlantic climate-ocean variations and sea level in long island Sound, Connecticut, since 500 cal yr A.D. Quat. Res. 53, 89-97.

van de Plassche, O., Erkens, G., van Vliet, F., Brandsma, J., van der Borg, K., de Jong, A.F.M., 2006. Salt-marsh erosion associated with hurricane landfall in southern New England in the fifteenth and seventeenth centuries. Geology 34 829-832.

van de Plassche, O., van der Borg, K., de Jong, A.F.M., 1998. Sea level-climate correlation during the past 1400 yr. Geology 26, 319-322.

Vane, C.H., Chenery, S.R., Harrison, I., Kim, A.W., Moss-Hayes, V., Jones, D.G., 2011. Chemical signatures of the Anthropocene in the Clyde estuary, UK: sedimenthosted $\mathrm{Pb},{ }^{207 / 206} \mathrm{~Pb}$, total petroleum hydrocarbon, polyaromatic hydrocarbon and polychlorinated biphenyl pollution records. Phil. Trans. R. Soc. A Math. Phys. Eng. Sci. 369, 1085-1111.

Vane, C.H., Jones, D.G., Lister, T.R., 2009. Mercury contamination in surface sediments and sediment cores of the Mersey Estuary, UK. Mar. Pollut. Bull. 58, 940-946.

Vane, C.H., Kim, A.W., Moss-Hayes, V., Snape, C.E., Diaz, M.C., Khan, N.S. Engelhart, S.E., Horton, B.P., 2013. Degradation of mangrove tissues by arborea termites (Nasutitermes acajutlae) and their role in the mangrove C cycle (Puerto Rico): chemical characterization and organic matter provenance using bulk $\delta^{13} \mathrm{C}, \mathrm{C} / \mathrm{N}$, alkaline CuO oxidation-GC/MS, and solid-state ${ }^{13} \mathrm{C}$ NMR. Geochem. Geophys. Geosys. (n/a-n/a).

Wacker, P.O., 1975. Land and People: a Cultural Geography of Preindustrial New Jersey: Origins and Settlement Patterns. Rutgers University Press, Newark, NJ.

Wacker, P.O., Clemens, P.G.E., 1994. Land Use in Early New Jersey; a Historical Geography. Rutgers University Press, Newark, NJ.

Warneke, T., Croudace, I.W., Warwick, P.E., Taylor, R.N., 2002. A new ground-level fallout record of uranium and plutonium isotopes for northern temperate latitudes. Earth Planet. Sci. Lett. 203, 1047-1057.

Wilson, G.P., Lamb, A.L., Leng, M.J., Gonzalez, S., Huddart, D., 2005. $\mathrm{d}^{13} \mathrm{C}$ and C/N as potential coastal palaeoenvironmental indicators in the Mersey Estuary, UK. Quat. Sci. Rev. 24, 2015-2029.

Yang, Z., Myers, E.P., Wong, A., White, S., 2008. Vdatum for Chesapeake Bay, Delaware Bay, and Adjacent Coastal Water Areas: Tidal Datums and Sea Surface Topography, NOAA Technical Memorandum NOS CS 15. U.S. Department of Commerce, National Oceanic and Atmospheric Administration, Silver Spring, Maryland, p. 110.

Yin, J., Schlesinger, M.E., Stouffer, R.J., 2009. Model projections of rapid sea-level rise on the northeast coast of the United States. Nat. Geosci. 2, 262-266. 